\title{
Developmental Expression of Reactivity to Monoclonal Antibodies Generated Against Olfactory Epithelia
}

\author{
Virginia McMillan Carr, ${ }^{1}$ Albert I. Farbman, ${ }^{1}$ Michael S. Lidow, ${ }^{1, a}$ Lynn M. Colletti, ${ }^{1}$ James L. Hempstead, ${ }^{2}$ and \\ James I. Morgan² \\ 'Department of Neurobiology and Physiology, Northwestern University, Evanston, Illinois 60208, and 2Department of \\ Neuroscience, Roche Institute of Molecular Biology, Roche Research Center, Nutley, New Jersey 07110
}

The developmental expression of immunocytochemical reactivity to 3 monoclonal antibodies (Mabs Neu 4, Neu 5, and Neu 9) that were generated against adult rat olfactory epithelium was examined in olfactory tissues of embryonic rats. Tissues examined included the nasal olfactory epithelium, nerve, and olfactory bulb, as well as vomeronasal epithelium and nerve. Reactivity patterns of these Mabs in adult rats have been described previously (Hempstead and Morgan, 1985a). All 3 Mabs show reactivity on the cell surfaces of neurons, axons, and dendrites of the olfactory epithelium proper. Neu 5 alone shows reactivity on the dendritic knobs, site of transduction of the olfactory stimuli. These reactivities appear early, suggesting developmentally significant roles for the antigens to these Mabs. For Neu 5 and Neu 9 initial reactivity occurs on outgrowing olfactory axons at E13. Dendritic and perikaryal reactivities begin appearing at $E 14$. For Neu 4 initial reactivity occurs simultaneously on olfactory neuronal perikarya, axons, and dendrites at E14. Reactivity also occurs on cells that migrate from the olfactory epithelium and are associated with the olfactory nerves. Within the developing olfactory bulb, Neu 5 behaves as a general cellsurface marker. Neu 4 and Neu 9, however, show enhanced reactivity in the glomerular layer after the onset of synaptogenesis. Reactivity is also seen in the nasal respiratory epithelium and in the vomeronasal epithelia and nerve.

Neu 5 and several antibodies to rat neural cell adhesion molecules (N-CAMs) show similar, although not identical, immunohistochemical staining patterns. They also react with the same bands in Western blots of brain membrane preparations. Western blots of Neu 5-reactive material also show developmental and spatial correlations of apparent molecular-weight distributions expected of N-CAM-like components as well.

The olfactory system is extremely useful for the examination of neural development and regeneration. Its morphological and synaptic organization and development have been well studied

\footnotetext{
Received May 23, 1988; revised July 31, 1988; accepted Sept. 13, 1988.

The very helpful technical assistance of Mr. Lauren D. Rentfro is gratcfully acknowledged. We thank Dr. R. Akeson for providing anti-N-CAMs monoclonal and polyclonal antibodies used in this study. This work was supported by NIH Grant NS 23348

Correspondence should be addressed to Dr. Virginia McM. Carr at the above address.

"Present address: Section of Neuroanatomy, Yale University, 333 Cedar Street, New Haven, CT 06510.

Copyright (C) 1989 Society for Neuroscience $0270-6474 / 89 / 041179-20 \$ 02.00 / 0$
}

(e.g., see Hinds, 1968a, b, 1972a, b; Cuschieri and Bannister, 1975a, b; Bayer, 1983; Brunjes and Frazier, 1986; Farbman, 1986; Farbman and Menco, 1986; Garrosa et al., 1986; Kratzing, 1986). The olfactory system of vertebrates is also unique among neural systems in several respects. One is the direct contact that the primary olfactory receptor neurons have with the external environment. Another is the continual neurogenesis and replacement of the primary sensory neurons that is maintained throughout the life of the individual (Moulton, 1974; Graziadei and Monti Graziadei, 1978) and that provides a means of complete reconstitution of the olfactory epithelium following its total surgical or chemical destruction (Monti Graziadei and Graziadei, 1979; Mair et al., 1982). In this regard it is notable that several biochemical moieties, such as the cell adhesion molecules N-CAM and Ng-CAM (Chuong and Edelman, 1984; Grumet et al., 1984; Daniloff et al., 1986), vimentin (Schwob et al., 1986), and the Thy-1 antigen (Morris et al., 1983) in the olfactory epithelium, bulb, or nerves occur at levels characteristic of immature rather than mature neurons even in the adult. Finally, olfactory receptor cell axons have a pronounced ability to form glomerular-like structures in whatever CNS region to which they project, whether it is their natural or an experimental target. It has been suggested that these "glomeruli" are primarily due to specific recognition, sorting out, and interaction among receptor cell axons with subsequent interaction with dendrites of second-order neurons (Graziadei and Monti Graziadei, 1986). Thus, elucidation of olfactory development at the molecular level would provide a wealth of information relevant to understanding neural development in general.

This kind of information could also be useful in understanding olfactory function, for olfactory responses have been shown to develop early. Electro-olfactograms are first demonstrable in the rat by the 14th embryonic day (E14), and action potentials can be generated by olfactory receptor neurons as early as E16 (Gesteland et al., 1982). Selective responsiveness to odorants is evident in some cells by E17. Moreover, at least some odorants have been shown to cause an increase in the activity of G-protein-dependent adenyl cyclase (Pace et al., 1985; Sklar et al., 1986; Anholt et al., 1987). 'Thus, the monitoring of ontogenic expression of olfactory markers may permit identification of mechanisms important in olfactory function.

To this end, several studies have examined the ontogenic expression of various molecular entities in the olfactory epithelium. These include the olfactory marker protein, OMP (Farbman and Margolis, 1980; Monti Graziadei et al., 1980; Allen and Akeson, 1985), the $\mathrm{H}$ and $\mathrm{B}$ blood group antigens (Mollicone et al., 1985), and carnosine synthetase (Margolis et al., 
1985), as well as immunoreactivity to monoclonal antibodies, or Mabs (Allen and Akeson, 1985).

Previous reports by one of our laboratories have described a panel of Mabs that interact with various components of the olfactory system under normal conditions and following olfactory bulbectomy in adult rats (Hempstead and Morgan, 1983, $1985 a, b)$. Several of these Mabs were shown to react with cellsurface components of the olfactory receptor cells and cell processes. The present studies were undertaken to examine the developmental expression of 3 of these Mabs, Neu 4, Neu 5, and Neu 9. These particular Mabs showed pronounced immunoreactivity with neurons, dendrites, and axons of the adult olfactory epithelium as well as changes in reactivity patterns following olfactory bulbectomy in the previous studies. The components of the olfactory system examined include the nasal and vomeronasal epithelia, their centripetal nerves, and the main olfactory bulb. We find that these Mabs show changes in the expression of their antigenic moieties that correlate with the major events of embryonic olfactory development. We also find that Neu 5 and several antibodies to rat neural cell adhesion molecules, N-CAMs, react with bands having the same apparent molecular weights on Western blots and show similar, although not identical, immunohistological reactivity patterns. It is hoped that through the use of markers such as these the molecular processes involved in the development of the olfactory system will be unravelled.

\section{Materials and Methods}

Immunocytological examination was carried out on cryostat sections through the olfactory epithelium and olfactory bulb of rat embryos, days E12-E22. Day E1 was counted as the day when the mothers were sperm positive. Mothers were anesthetized by intraperitoneal injection of sodium pentobarbital (12-15 mg/animal), and the embryos were promptly removed. Embryos at E12-E18 were fixed by immersion in 4\% paraformaldehyde in $0.1 \mathrm{~m}$ Sorenson's phosphate buffer, $\mathrm{pH}$ 7.3. Embryos at E19 and older were fixed by perfusion of the fixative into the left cardiac ventricle preceded by a brief perfusion with buffer to wash out the blood. Fixed animals were decapitated and extraneous tissue dissected away from the snouts and forebrain region. Fixation was continued for $24 \mathrm{hr}$. Specimens were washed several times in Sorenson's phosphate buffer, placed in $25 \%$ sucrose for $1-2 \mathrm{~d}$ and then embedded in O.C.T. Compound (Miles Scientific, Naperville, IL). Subsequently, they were sectioned in a cryostat or stored at $-80^{\circ} \mathrm{C}$ until used. Section thickness was 7-8 $\mu \mathrm{m}$. Sections were mounted on formaldehyde crosslinked gelatin-alum-subbed slides and processed for indirect immunofluorescence.

The procedures used for indirect immunofluorescence have been described previously (Morgan, 1984). Primary antibodies, used at various dilutions, were the Mabs Neu 4, Neu 5, and Neu 9 previously raised against adult rat olfactory epithelia in BALB/c mice (Hempstead and Morgan, 1985a). In one set of experiments a Mab to rat N-CAMs (3F4.18, kindly provided by R. Akeson, University of Cincinnati; see Williams et al., 1985) was used as the primary antibody. PBS or NUC, a Mab that specifically reacts with cell nuclei, was used in placc of the Mabs in control reactions. The secondary antibody was FITC-conjugated goat anti-mouse immunoglobulin mixture (IgG + IgA + IgM; Cappel, Malvern, PA), diluted 1:29 with PBS. Normal goat serum (NGS, GIBCO Laboratories, Grand Island, NY), diluted 1:1 with PBS, served as the blocking agent in all immunohistological procedures.

To determine the degree of cross-reactivity between $\mathrm{Neu} 4$ and Neu 9 , double-labeling procedures were run using both Neu 4 and Neu 9 as primary antibodies and rhodamine-conjugated immunoglobulin mixture (IgG+IgA+IgM; Cappel), as well as the FITC-conjugate as secondary antibodies. In these experiments cryostat sections were first exposed to one of the primary antibodies and one of the secondary antibodies as usual. This treatment was followed immediately by a second set of reactions using the remaining primary and secondary antibodics. The order of presentation of both the primary and secondary antibodies was varied to control for any effects this presentation se- quence might have. A similar double-labeling procedure was run to compare reactivity of Neu 5 and the $3 F 4.18 \mathrm{Mab}$ to N-CAMs.

Slides were coverslipped using a glycerol-gelatin mixture (Sigma Laboratories, St. Louis). Just before coverslipping slides were dipped in a solution of $\mathrm{NaI}$ ( $50 \mathrm{gm} /$ liter PBS, pH 8.2). This retards both rapid and long-term fading of FITC fluorescence (Johnson et al., 1982; Böck et al., 1985) and was found to greatly enhance the clarity of the fluorescent image obtained.

Sections were examined and photographed on a Leitz Laborlux D microscope fitted with epifluorescent and phase-contrast optics, which allowed us to visualize both reactive and nonreactive cells.

Some sections at various ages were also stained by an immunoperoxidase procedure, using a Vectastain $\mathrm{ABC}$ kit based on mouse IgGs (Vector Laboratories, Burlingame, CA). A solution of 50\% NGS and $5 \%$ nonfat dried milk in PBS was used as the blocking agent in place of that supplied with the kit. The peroxidase substrate solution was $0.01 \%$ hydrogen peroxide and $0.05 \%$ diaminobenzidine in $0.05 \mathrm{M}$ Tris buffer prepared as directed.

For electron microscope immunocytochemistry, E19, E20, and E21 fetuses were fixed as described above in buffered $4 \%$ paraformaldehyde and sectioned at $60-100 \mu \mathrm{m}$ with a Vibratome. The sections were incubated as described above with the peroxidase method except that 2 $5 \%$ dimethylsulfoxide (DMSO) was added to all solutions containing antibodies. Following the final wash, specimens were fixed in $1 \% \mathrm{OsO}_{4}$, dehydrated in an ascending series of ethanols, and processed for examination with the electron microscope.

Biochemical techniques. Fetal, neonatal, and adult rat tissues were homogenized in Laemmli dissociation buffer (Laemmli, 1970) and centrifuged at $12,000 \times g$ to remove larger cytoplasmic components. Supernatants were diluted $1: 1$ with sample buffer $(0.125 \mathrm{~m}$ Tris base, $\mathrm{pH}$ $6.8,20 \%$ glycerol, $10 \% 2$-mercaptoethanol, and $4.6 \%$ SDS). Samples and molecular-weight standards were boiled for $5 \mathrm{~min}$, analyzcd for protein content (Lowry et al., 1951; or Bio-Rad Protein Assay Kit, BioRad Laboratories, Richmond, CA), and subjected to SDS-PAGE. Initial gels were $10 \%$ acrylamide. Western blots were made (modified from Towbin et al., 1979) and analyzed for the presence of Neu 4, Neu 5, and Neu 9 antigens. The specimens were blocked with $1 \%$ gelatin and exposed to each of the 3 Mabs. Following a wash in PBS, bound antibody was revealed by incubation of the nitrocellulose filter with peroxidasecoupled anti-mouse immunoglobulin, washed, and exposed to hydrogen peroxide/2-chloronaphthol as the peroxidase substrate/chromophore solution. Coomassie blue prestained molecular-weight-standard proteins were run on the same gel and transferred with the test samples.

A second series of immunoblots was carried out to compare the reactivity of Neu 5 with that of several antibodies to rat N-CAMs (Mabs $3 \mathrm{G} 6.41$ and $3 \mathrm{~F} 4.18$ and polyclonal antibody 161 , provided by R. Akcson). In this series membrane fractions of postnatal day (P) 23 rat brains were examined because immunohistological patterns showed Neu 5 reactivity to be membrane associated. Samples were homogenized in the Tris-EDTA buffer of Telser et al. (1982) minus aprotinin and centrifuged at $1000 \times g$ for $10 \mathrm{~min}$ and then at $25,000 \times \mathrm{g}$ for $30 \mathrm{~min}$. The membrane fraction was resuspended in the Tris-EDTA buffer and diluted with sample buffer $[0.062 \mathrm{M}$ Tris- $\mathrm{HCl}, \mathrm{pH} 6.8,10 \%$ glycerol, $2 \%$ SDS, 5\% 2-mercaptoethanol, and $0.0012 \%$ each bromophenol blue and pyronin $G(Y)$ ]. Samples and high-molecular-weight standards (BioRad) were boiled for $5 \mathrm{~min}$ and run on 10 or $7.5 \%$ acrylamide gels. Blots were stained using the Vectastain $\mathrm{ABC}$ kit with the hydrogen peroxide/diaminobenzidine mixture as the peroxidase substrate/chromophore solution.

Explant cultures on gold grids. Three female rats, on day 16 of gestation, were killed with an overdose of $\mathrm{CO}_{2}$. Fetuses were removed under sterile conditions. The olfactory mucosa was dissected out, placed into Waymouth's MB752/1 culture medium (GIBCO), and minced into very small pieces, $0.2-0.5 \mathrm{~mm}^{3}$. Drops of the medium containing the olfactory mucosal cells were deposited on $3.0 \mathrm{~mm}$ gold grids ( $300 \mathrm{mesh}$ ). The grids had been previously coated with Formvar film (cast from a $1 \%$ solution of Formvar in 1,2-dichloroethane) and then by $0.1 \mathrm{mg} / \mathrm{ml}$ polyornithine (PORN) in $0.1 \mathrm{~m}$ borate buffer, pH 8.3 (Gonzales et al., 1985 ) and placed in the $35 \mathrm{~mm}$ culture dishes. The dishes with grids were incubated for $48 \mathrm{hr}$ in a humidified $5 \% \mathrm{CO}_{2}$ atmosphere at $37^{\circ} \mathrm{C}$. During that period the small fragments of olfactory mucosa became attached to the substrate and produced some axonal growth. At the end of incubation, the grids were taken out of the dishes and placed at room tempcrature for $1 \mathrm{hr}$ in a pcriodatc-lysinc-paraformaldchyde fixativc (McLean and Nakane, 1974). They then were washed in PBS and placed 
in $25 \%$ NGS and 5\% BSA in PBS for $30 \mathrm{~min}$ at room temperature. Afterwards, grids were placed for $1 \mathrm{hr}$ at room temperature in a solution containing a primary antibody. Grids were washed in PBS, and staining was continued with the Vectastain $\mathrm{ABC}$ kit as described. Finally, grids were postfixed with $1 \% \mathrm{OsO}_{4}$ in PBS for $1 \mathrm{hr}$, dehydrated in a series of alcohols, and dried at the critical point of liquid $\mathrm{CO}_{2}$. Axons and their terminals were examined directly in this whole mount with a JEOL $100 \mathrm{CX}$ electron microscope at $120 \mathrm{kV}$.

\section{Results}

Neu 5

\section{Nasal epithelia}

Neu 5 reactivity first occurs in olfactory axons and their associated cells in the E13 rat embryo, shortly after the nasal cavity invaginates (Fig. 1). Some sections of the ventrolateral telencephalon also appear to have faint basal pericellular reactivity.

Convincing pericellular staining is not apparent in the olfactory epithelium until a day later, at E14, when scattered single or small groups of reactive receptor cells occur, predominantly in the mid to basal portion of the dorsal epithelium (Fig. 2a). Initially there are more reactive cells in the olfactory epithelium on the medial than on the lateral surfaces of the nasal cavity. Reactive dendrites and axons appear. The axons can be seen leaving the epithelium and fasciculating with others to form the intensely fluorescent olfactory nerve bundles.

With continued development the number of reactive cells increases (Fig. $2 b$ ), and, by E15, Neu 5-positive cells can be found uniformly throughout much of the anterodorsal-most olfactory epithelium, especially on the medial nasal surfaces. More caudally and ventrally, where the stage of development lags slightly behind, the reactive cells tend to be confined more to the middle and basal regions of the epithelium.

By E16 the olfactory epithelium is noticeably thicker and there are more Neu 5-positive cells (Fig. 2c). The reactive cell bodies are concentrated predominantly in the basal to mid olfactory epithelium dorsally and in the midepithelium along the sides of the nasal cavity. Supporting cells appear unreactive at the light microscope level.

Reactive dendritic knobs are scarce until E18 when brightly fluorescent knobs can be seen projecting slightly into the lumen. Knobs increase greatly in number by E19 (Fig. 2d). Electron microscopy shows that the entire dendritic knob surface, including the cilia, is covered with Neu 5 reactivity (Fig. $3 a$ ). What may be a small locus of Neu 5 reactivity can also be seen at the ultrastructural level on the surface of some supporting cells immediately adjacent to reactive dendritic knobs. This reactivity appears confined to a region of the supporting cell surface within $0.5-1.5 \mu \mathrm{m}$ of a neighboring knob. Whether it is real or artifactual remains to be determined.

No further change in this Neu 5 olfactory reactivity pattern occurs through E23, the end of embryogenesis.

Because Western blot analysis showed close similarities between Neu 5-reactive material and N-CAMs (see below), sections from rats of various ages were treated with polyclonal antibodies to rat N-CAMs for comparison with Neu 5 immunoreactivity. By E19 the reactivity patterns obtained were very similar to those of Neu 5 (Fig. 4). However, at E14 and E15, when Neu 5 stained single cells or groups of cells in the olfactory epithelium, anti-N-CAMs more often gave fairly uniform staining of the entire olfactory epithelium. Moreover, at the ultrastructural level, anti-N-CAMs showed no reactivity with the tips of the olfactory dendritic knobs in more mature embryos.

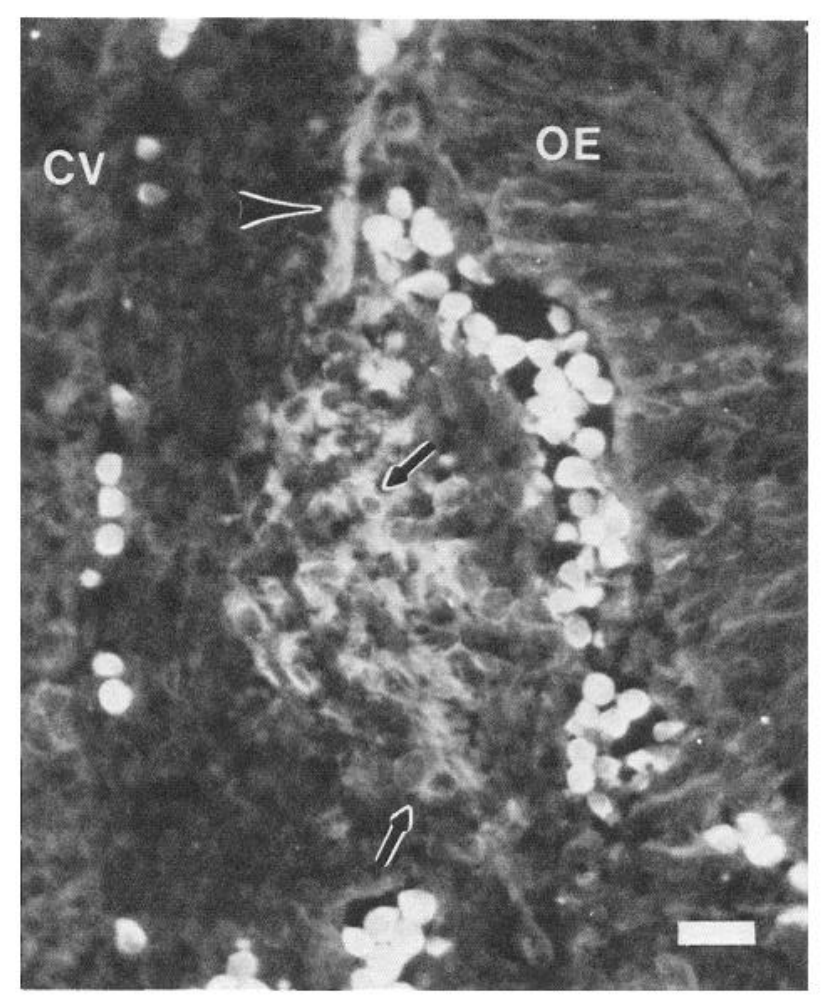

Figure 1. Section through the head of an E13 rat embryo stained by the Neu 5 Mab. Early Neu 5 immunofluorescent reactivity occurs on the outgrowing olfactory nerve between the olfactory epithelium $(O E)$ and the site of the presumptive olfactory bulb in the ventral anterior cerebral vesicle $(\mathrm{CV})$. Wispy fluorescent axonal material is apparent, as is the pericellular fluorescence of associated cells (e.g., arrows). Axon bundles can be seen growing from the olfactory epithelium toward the bulk of the olfactory nerve (arrowhead). The bright cytoplasmic fluorescence is yellow autofluorescence of red blood cells under the excitation illumination for fluorescein. Scale bar, $20 \mu \mathrm{m}$.

In the nasal respiratory epithelium a few reactive cells and cell processes occur near the luminal surface at E14 and E15 (Fig. 5a). Later, at E18, relatively weak pericellular Neu 5 reactivity appears on the basal-most cells (Fig. $5 b$ ). This basal location of these reactive cells is a change from the luminal location observed earlier. Reactivity also appears in respiratory basal lamina at this time, and small patches of discontinuous fluorescence begin to appear on the luminal surface of some respiratory cells. Increasing numbers of respiratory cells show this luminal reactivity, until by E22 it covers most of the respiratory luminal surface. Electron micrographs (not included) show that this luminal reactivity is located primarily on microvilli and, to a lesser extent, cilia. These changes are coincident with the maturation of microvilli and cilia in the respiratory epithelium (Menco and Farbman, 1987).

\section{Vomeronasal organ (VNO)}

The VNO is an accessory olfactory structure that evaginates from the medial wall of the nasal cavity and elongates posteriorly at the base of the nasal septum. At E14-E16 the cellular pattern of Neu 5 reactivity in the VNO is similar to that of the nasal olfactory epithelium proper, with surface reactivity appearing on receptor cell bodies, axons, and dendrites. Reactive cells occur predominantly in the mid to basal half of the VNO epithelium (Fig. 6, $a-c$ ) until E18-E19, when their number has so 

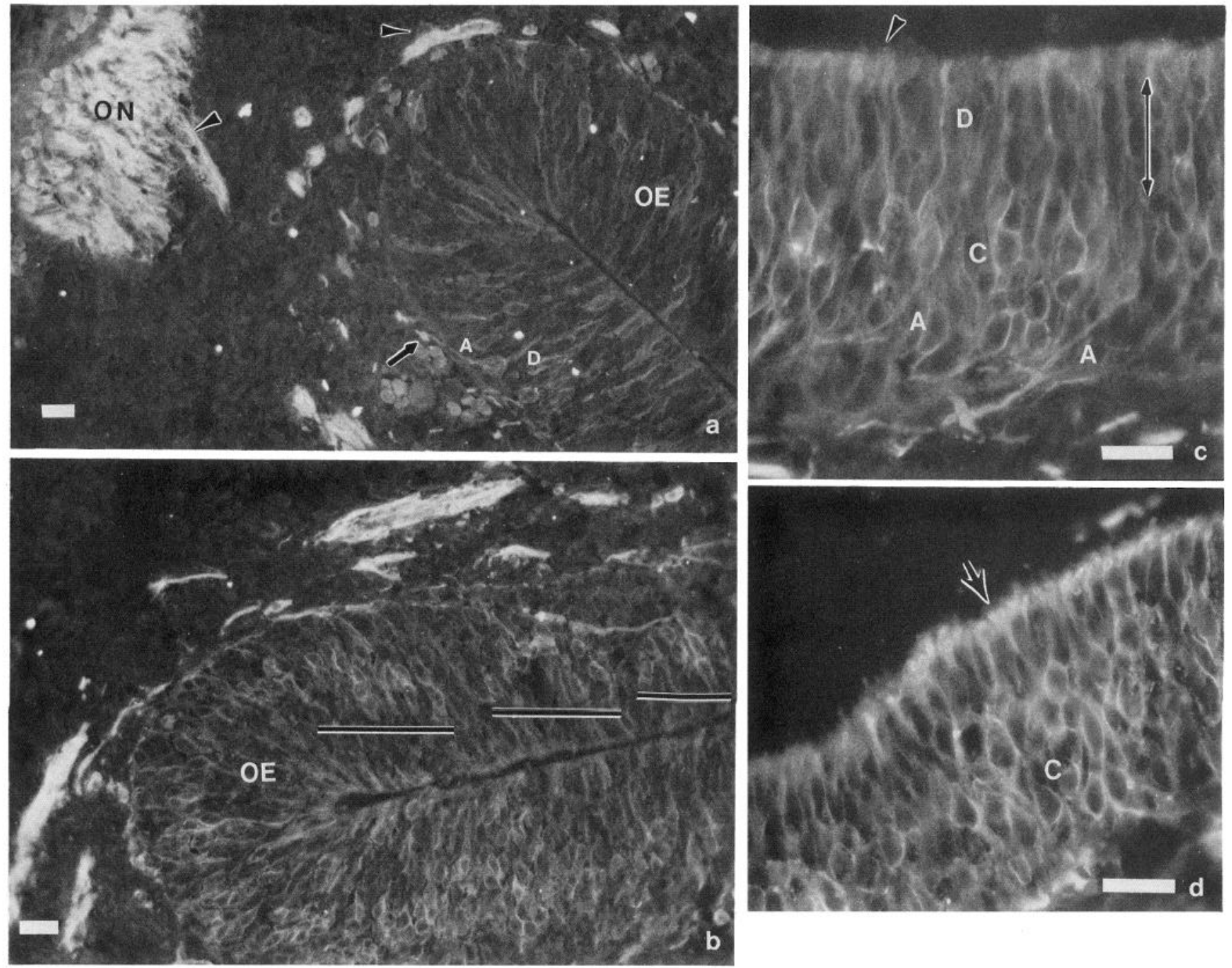

Figure 2. Neu 5 immunofluorescent reactivity in the nasal olfactory epithelium and nerves. $a$, Dorsal epithelium $(O E)$ and olfactory nerve $(O N)$ at E14. Neu 5-reactive cells, their axons $(A)$, and/or dendrites $(D)$ are apparent, predominantly in the mid to basal region of the epithelium. Reactive cells are more numerous in the medial (lower) than lateral (upper) epithelium. Axonal reactivity seems to intensify as axons leave the epithelium, fasciculate, and grow toward (arrow) the olfactory nerve. Cells showing pericellular reactivity are associated with the nerve (e.g., arrowheads). $b, \mathrm{E} 15$. The same features are apparent but reactive epithelial cells have increased in number. In the medial (lower) epithelium, the reactive cells are numerous and uniformly distributed. In the lateral (upper) epithelium, the reactive cells are fewer and remain clustered (bars). $c$ and $d$, Olfactory epithelium, higher magnification. $c$, E16. Reactive cell bodies $(C)$, axons $(A)$, and dendrites $(D)$ are apparent. Occasional reactive dendritic knobs can be seen (arrow). Pericellular staining is not apparent in the supporting cell layer (double-headed arrow). $d$, E19. Reactivity on olfactory receptor cells $(C)$ and their dendritic knobs (arrow). Scale bars, $20 \mu \mathrm{m}$.

increased that their distribution becomes uniform (Fig. 6d). At this stage, Neu 5-reactive dendritic knobs can first be seen in the VNO olfactory epithelium, as was also the case in the nasal olfactory tissue. However, in the VNO the Neu 5-reactive dendritic knobs appear broader, are less reactive, and project into the VNO lumen much less than their nasal counterparts (cf. Figs. $6 e$ and $2 d$ ).

The receptor-free epithelium (Breipohl et al., 1979) of the VNO initially shows a Neu 5 reactivity pattern similar to that of the VNO olfactory epithelium except that reactive cells are scattered throughout the entire thickness of the receptor-free epithelium rather than being concentrated in the mid to basal half. By E16, however, a decline begins in the number of reactive cell processes that traverse the receptor-free epithelium (Fig. 6, $b, c)$. By E19 these reactive processes have disappeared entirely, and the receptor-free epithelium has been reduced in width to only 1-3 cells. A loss of Neu 5-reactive cells also occurs (Fig. $6, b, c)$ such that by E19 only a few large, rounded cells still show Neu 5 reactivity. Finally, a few scattered brightly fluorescent small dots appear in the middle of the receptor-free epithelium at about E18. These probably represent trigeminal fibers to the receptor-free epithelium (see Tucker, 1971, and Cauna et al., 1969).

\section{Olfactory and vomeronasal nerves}

Between E13 and E14 the Neu 5-reactive olfactory nerve bundles enlarge greatly and become intensely immunofluorescent. They can be readily followed as they aggregate at the ventral surface of the cerebral vesicle (Fig. 2a). Fibers extend from this aggregate to form a crescent of bright fluorescence that extends part way up the sides of the anterior cerebral vesicle, site of the presumptive olfactory bulb. As development proceeds, this cres- 

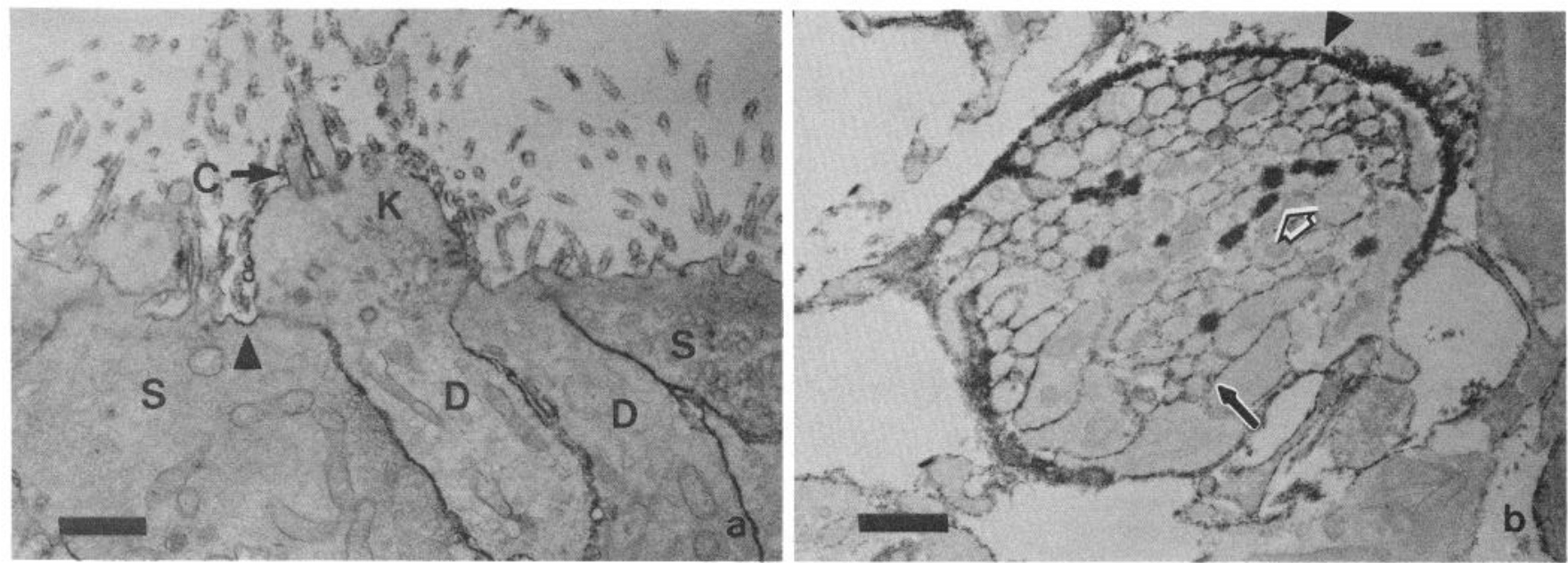

Figure 3. Electron micrographs of Neu 5 immunoperoxidase reactivity at E19. $a$, Olfactory epithelium with reactivity apparent on receptor cell dendrites $(D)$, knobs $(K)$, and cilia $(C)$. Supporting cells $(S)$ are generally unreactive, although what may be reactivity can be seen occasionally on supporting cell surfaces in the region immediately adjacent to dendritic knobs (arrowhead). $b$, Olfactory nerve bundles show strong reactivity on the surface of individual axons (small arrow) and axonal bundles (arrowhead). Apparent axoplasmic reactivity (open arrow) is discussed in the text. Scale bars, $1 \mu \mathrm{m}$.

cent of reactive material grows until it surrounds the entire developing bulb, thereby forming the olfactory nerve layer (ONL) of the bulb. Electron microscopy of the nerve bundles shows that Neu 5 reactivity is generally confined to the surface of individual olfactory axons and nerve bundles (Fig. $3 b$ ), although some apparent axoplasmic reactivity can also be seen. Similar axoplasmic reactivity is seen with Mabs to N-CAM, a known surface moiety (Blackenbury et al., 1977; Rutishauser et al., 1978). However, it does not appear in control preparations in which PBS replaced the primary antibodies and, thus, may represent axoplasmic transport of Neu 5 antigens.

Within the olfactory nerve bundles and the developing ONL the outlines of many cell bodies can be seen throughout embryogenesis (Fig. 7a). The density of these cells seems to be particularly high where the olfactory nerve approaches the bulb and merges with the ONL (Fig. $7 b$ ). Most show a distinct rim of pericellular Neu 5 reactivity.
Neu 5 reactivity in vomeronasal nerve bundles, including the associated cells, is similar to that of the olfactory nerve proper.

\section{Olfactory bulb}

At E14 and E15 the presumptive olfactory bulbs show distinct but faint Neu 5 pericellular reactivity revealing the radial cellular arrangement of the matrix and the more random arrangement of the mantle regions (Fig. 8a). By E16 in some areas a more fibrous reactivity also begins to appear in the region just subjacent to the ONL. The most intense Neu 5 reactivity is found in the olfactory nerve fibers that are growing dorsally around the developing bulb; a clear demarcation can be seen between the developing ONL and the rest of the presumptive bulb. The ONL remains the most intensely reactive layer of the bulb with Neu 5 throughout embryonic development.

By E18 (Fig. $8 b$ ) there is a dense fibrous reactivity, but of a
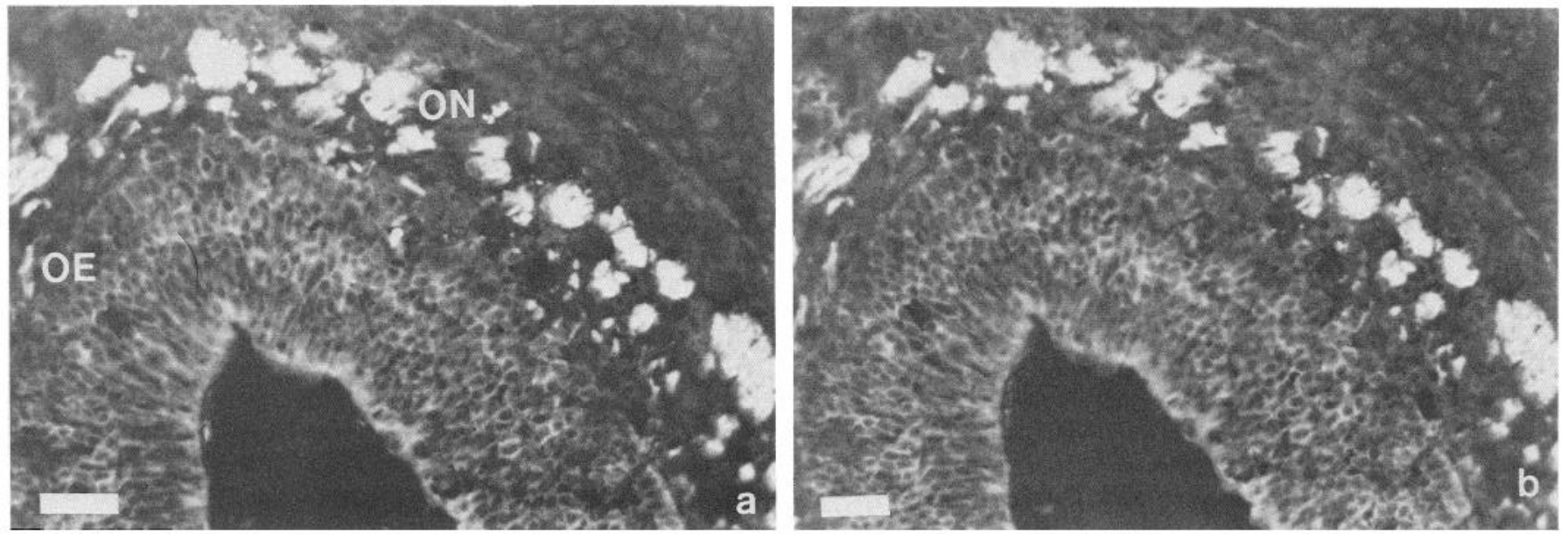

Figure 4. Section through olfactory epithelium $(O E)$ and olfactory nerve bundles $(O N)$ of an E19 embryo reacted sequentially with anti-N-CAMs as the primary antibody and FITC-conjugated goat anti-mouse immunoglobulin mixture as the secondary antibody and then with Neu 5 as the primary antibody and rhodamine-conjugated goat anti-mouse immunoglobulin mixture as the secondary antibody. Exposure for FITC (a) and rhodamine $(b)$. The similarity in staining patterns is obvious. Scale bars, $40 \mu \mathrm{m}$. 


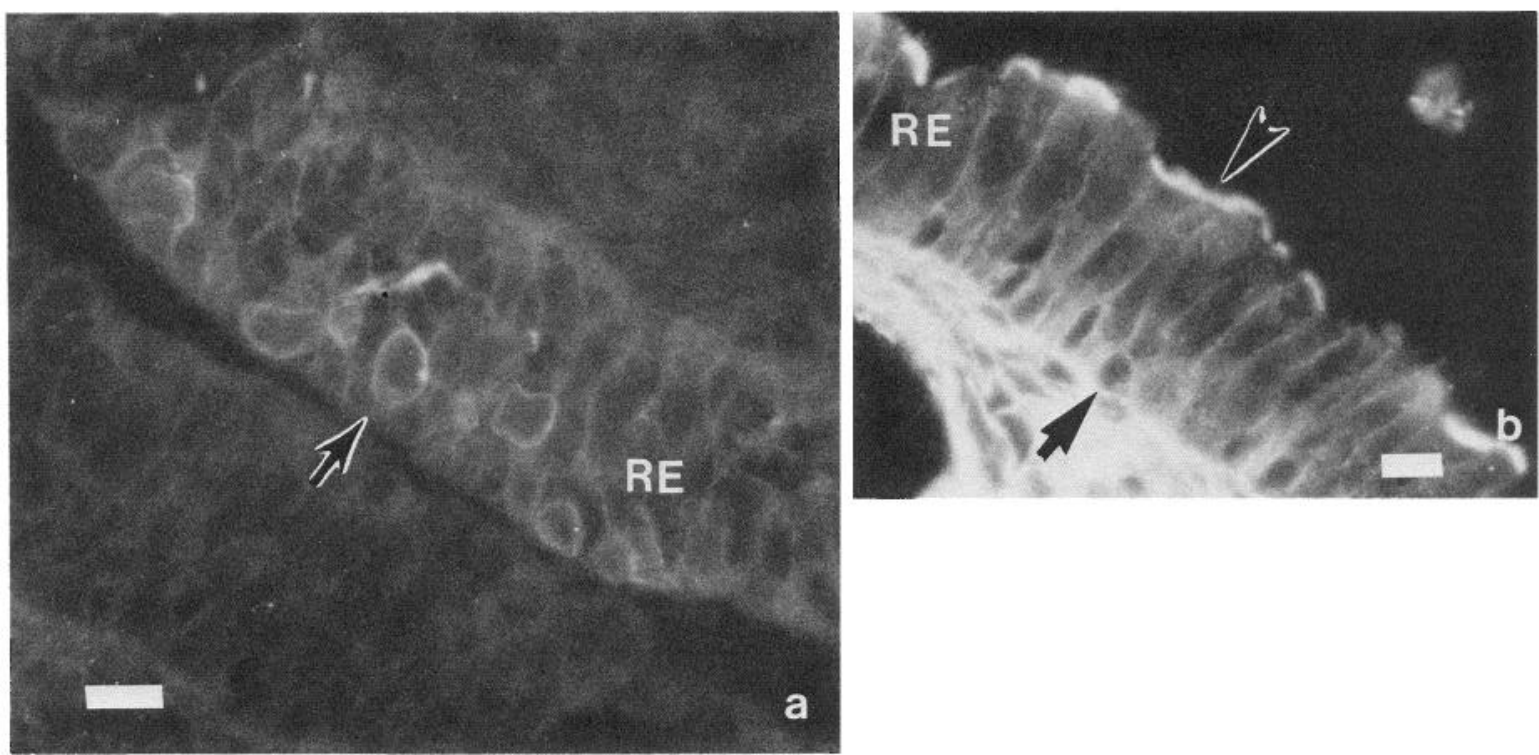

Figure 5. Neu 5 reactivity in the respiratory epithelium $(R E)$. a, At E16, reactive cells are located apically (arrow). b, By E19, luminal reactivity appears (arrowhead), and basally located cells show pericellular reactivity (e.g., arrow). Note that most of the staining in the mesenchyme subjacent to the epithelium is nonspecific and is completely eliminated by presorption of the FITC-conjugated secondary antibody with normal rat serum, as described in the text. Scale bars, $10 \mu \mathrm{m}$.

much lower intensity, beneath the ONL, i.e., in the primitive external plexiform and glomerular layers [(EPL $+\mathrm{GL})$; terminology of Hinds, 1968b, at comparable developmental state in the mouse]. Strongly reactive fine fibers can occasionally be seen projecting inward to this layer from the ONL. The subjacent mitral cell layer (MCL) also appears at this time, as a concentric ring of large- and medium-sized Neu 5-reactive cells several layers thick. Internally, the random orientation of the cells of the intermediate zone (IZ) and subependymal layers is apparent.

At E19 (Fig. 8c) more fluorescent fibers from the ONL have penetrated into the bulb, and by E20 a few small rounded areas of diffuse Neu 5 reactivity, marking the initial formation of glomeruli, can be distinguished. By E22 (Fig. 8d) these glomeruli are numerous. The MCL has become quite clearly defined with many pericellularly reactive cells, both large and small, as well as radially oriented fluorescent fibers. Some of these fibers can clearly be seen emerging from the MCL cells. The granule cell layer (GCL) exhibits both cellular and fibrous reactivity. Finally, the matrix layer has disappeared entirely, leaving the subependymal region lining the ventricle. Fibrous elements and most, if not all, of the cells of the subependymal region are reactive with Neu 5.

\section{Neu 9}

\section{Nasal epithelia}

As with Neu 5, reactivity to Neu 9 is first apparent at E13 in the nerve bundles and their associated cells, between the developing nasal cavity and the ventrolateral telencephalon (Fig. 9). By E14 reactivity to Neu 9 has increased noticeably, and virtually all cells, including the supporting cells, exhibit pericellular reactivity (Fig. 10a). At E16 the basal lamina also becomes reactive to Neu 9.

By E17, the fluorescence intensity of the nerve bundles is distinctly greater than that of the olfactory epithelium itself. Within the epithelium a thickening in the reactive material near the lumen has become apparent (Fig. 10b). However, this reac- tivity does not extend as far as the dendritic knobs; and, in contrast to the staining with Neu 5, electron micrographs show that virtually all knobs remain unreactive with Neu 9 (Fig. 11a). Few changes in this reactivity pattern occur through the remainder of embryogenesis.

Pericellular and fibrous Neu 9 reactivity is also apparent in the respiratory epithelium by E16, though it is less intense than that of the olfactory epithelium and remains so throughout embryogenesis. Only 2 changes occur: one is a shift of the pericellular reactivity from an apical to a basal position; the other is the appearance of luminal surface reactivity. Both changes follow a pattern similar to that seen with $\mathrm{Neu} 5$, as illustrated in Figure 5.

\section{$V N O$}

Neu 9 reactivity in the VNO epithelium first appears at E14. This reactivity is pericellular and fibrous and is uniformly distributed throughout the entire epithelium, similar to that seen in the nasal olfactory epithelium at this stage but less intense. As was true for Neu 5, this initial VNO Neu 9 reactivity occurs in both the olfactory and receptor-free epithelia of the VNO and has a similar pattern in each.

By $\mathrm{E} 17$ reactivity declines and remains low through the rest of embryonic development, making photography difficult. Nevertheless, faint pericellular reactivity does occur on virtually all cells in the VNO receptor-free epithelium as well as cells predominantly in the basal half of the VNO olfactory epithelium. By E19 all reactivity has disappeared from the apical region of the olfactory epithelium and from the entire receptorfree epithelium. Only the transition zone between olfactory and receptor-free epithelia, the site of mitotic activity in the mature VNO (Barber and Raisman, 1978), shows pericellular reactivity, albeit faint, throughout the entire width of the epithelium. Dendritic reactivity also remains relatively weak. As with $\mathrm{Neu} \mathrm{5,} \mathrm{a}$ few very intensely fluorescent spots, likely due to trigeminal sensory input, appeared scattered throughout the VNO at about 

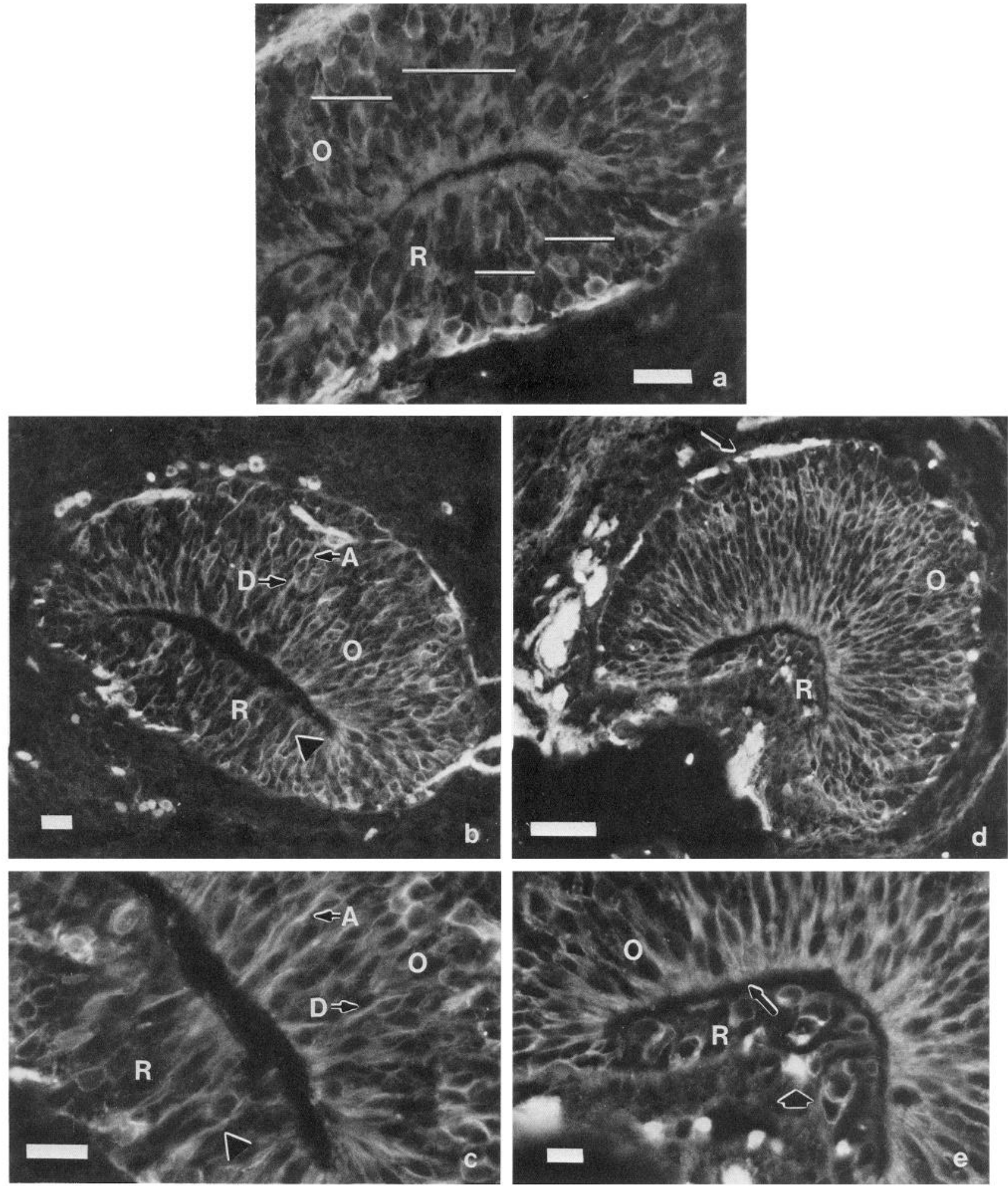

Figure 6. Neu 5 immunofluorescent reactivity in the VNO. a, E15. Reactive cells occur in small clusters $($ thin bars $)$ in both the olfactory $(O)$ and receptor-free $(R)$ epithelia. $b$, E16. Clustering still occurs. Reactive axons $(A)$ and dendrites $(D)$ can now be seen in the olfactory epithelium. Reactive processes also occur in the receptor-free epithelium (arrowhead). $c$, E16. Different section showing the same features at higher magnification. $d$, E19. Reactive cells now show a more uniform distribution. The most intensely reactive cells are found in the middle or basal half of the olfactory epithelium. Reactive dendrites and axons are numerous. The thickness of the receptor-free epithelium has been greatly reduced. Brightly fluorescent vomeronasal nerve bundles are apparent at the VNO surface (e.g., arrow). Some nonspecific mesenchymal reactivity, as described in the text, appears in the upper left-hand corner. $e$, E19, higher magnification. The VNO olfactory epithelium shows less intense staining and the VNO dendritic knobs (thin arrow) are much less obvious than in the nasal cavity (cf. Fig. 4a). In the receptor-free epithelium pericellular reactivity is apparent on several large round cells, but reactive processes are no longer seen. Very bright dots of fluorescent material (wide arrow) are also apparent, most likely due to Neu 5 reactivity in trigeminal nerve bundles as described in the text. Scale bars, $20 \mu \mathrm{m}(a-c), 40 \mu \mathrm{m}(d)$, and $10 \mu \mathrm{m}(e)$. 

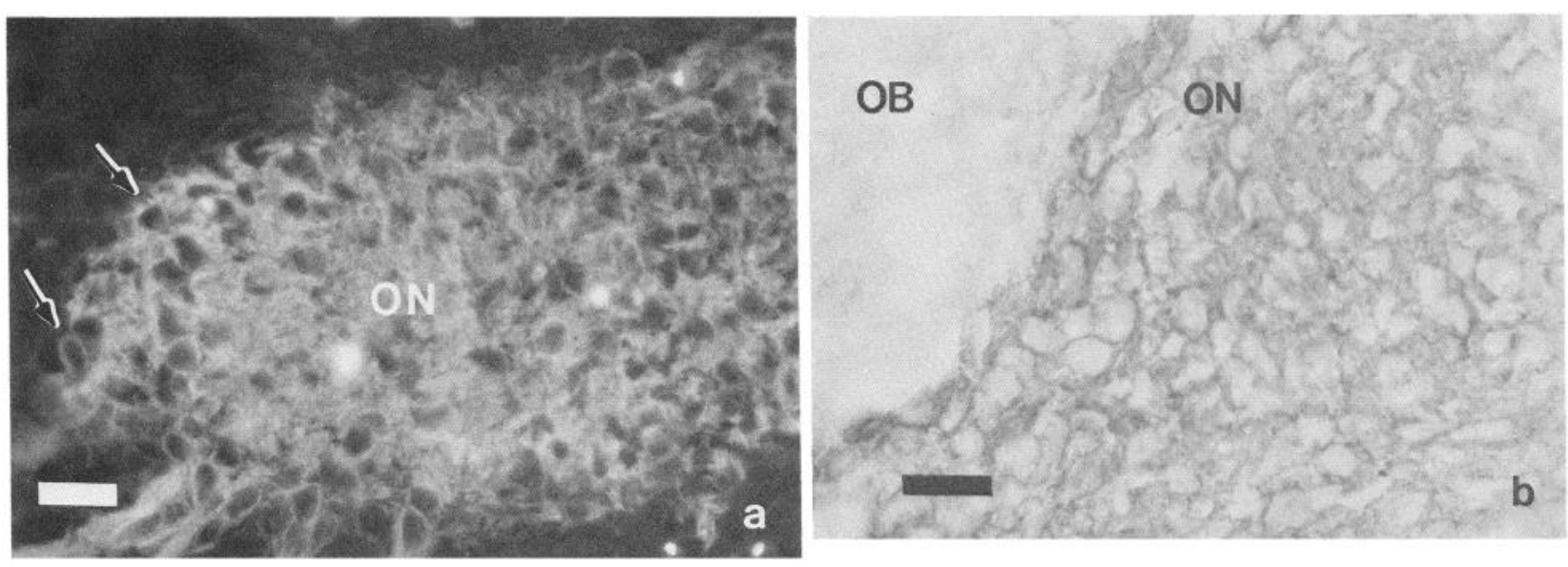

Figure 7. Neu 5 reactivity in the olfactory nerve at E15 in immunofluorescent $(a)$ and immunoperoxidase $(b)$ preparations showing the intensity of reactivity as well as the presence in the nerve of Neu 5-reactive cells. $a$, The olfactory nerve $(O N)$ between the developing olfactory bulb and olfactory epithelium (neither pictured but located, respectively, above and below the nerve). Reactive cells (e.g., arrows) show a preponderance on the leading dorsal surface and in association with axonal bundles from the olfactory epithelium joining the olfactory nerve ventrally. $b$, Where the olfactory nerve becomes apposed to the olfactory bulb $(O B)$, reactive cells are numerous. Scale bars, $20 \mu \mathrm{m}$.

this time. While most of these occur in the receptor-free epithelium, a few occur in the VNO olfactory tissue as well.

\section{Olfactory and vomeronasal nerves}

Neu 9 reactivity with the developing olfactory nerve fibers is similar to that seen with Neu 5, except that the overall intensity is noticeably less. Electron micrographs show that most of the reactivity is on the surface of the individual axons and axon bundles (Fig. 11b), although, as with Neu 5, a few scattered axons show axoplasmic staining as well. Neu 9 reactivity also occurs on cells associated with the olfactory nerve bundles (e.g., Fig. 9). Again as with Neu 5, these cells are especially apparent in the olfactory nerves just below and growing around the developing bulb (see Fig. 12a) and persist throughout embryogenesis.

The Neu 9 reactivity pattern of the vomeronasal nerves is quite similar. However, as noted above, the overall level of VNO fluorescence is relatively low; and, just where the VNO receptor cell axons emerge from the epithelium, their fluorescence intensity increases to match that of the nasal olfactory fibers proper.

\section{Olfactory bulb}

Within the presumptive bulb itself Neu 9 reactivity first appears at E14. It is most pronounced in the developing ONL but remains less intense than that of Neu 5. Occasional reactive processes can be seen at E14 and E15 growing deeply into the bulb from the developing ONL (Fig. 12a) but are not apparent after that. We assume these processes are axonal rather than glial because they do not react with antibodies to the glial fibrillary acidic protein GFAP (supplied by A. Bignami, V.A. Hospital, Roxbury, MA), which occurs in radial glia from very early stages of gliogenesis (Levitt et al., 1981) and which does begin to show reactivity in the bulb at E19 (not shown), and because at comparable stages in mouse embryos extremely few glial cells have even ceased mitotic activity (Hinds, 1968a). Some pericellular Neu 9 reactivity can be seen in the more external, mantle region. By E17 such Neu 9 pericellular reactivity becomes more obvious.

As described above in the Neu 5 section, striking changes in the bulbar organization begin to appear at E18 (Fig. 12b). At this time Neu 9 reactivity begins to increase in the region of the primitive (EPL+GL) just below the ONL, and by E19 and E20 the emerging GL has become the most intensely reactive layer in the bulb. This enhanced GL Neu 9 reactivity is in contrast to Neu 5, which shows its most intense bulbar reactivity in the ONL. In some regions of the developing GL, distinct aggregations of intensely reactive material mark the first appearance of distinct glomeruli with Neu 9. These glomeruli enlarge with further development. The immunofluorescence of these structures at E22 can be seen in Figure 12c.

Neu 9 reactivity becomes apparent in the subjacent MCL at E19 when this layer appears as a concentric layer of radially arranged large cells and some reactive fibers. Many of these cells show some degree of pericellular reactivity. In addition to reactive fibers passing through the MCL, Neu 9-reactive fibers can also occasionally be seen leaving the apical or central poles of some of the mitral cells.

The presumptive internal plexiform layer (IPL) and subjacent GCL begin to appear in late embryogenesis. At E19 the presumptive IPL region shows a bright amorphous reactivity as well as some pericellular reactivity. Because of the fibrous nature of the IPL and the immature state of development of the bulb at this age, this pericellular reactivity is presumably due to cells migrating through the layer. The intensity of Neu 9 reactivity in this layer increases noticeably by E22. The GCL reactivity is similar to that of the presumptive IPL but much less intense. Between E19 and E22 reactive cells in more superficial regions of the presumptive GCL become increasingly interspersed with reactive fibers. Little or no reactivity occurs in the subependymal layer.

\section{$\mathrm{Neu} 4$}

Neu 4 reactivity is first apparent at E14 as faint pericellular staining in nasal olfactory and VNO epithelia. Nevertheless, staining is ubiquitous and uniform throughout both these olfactory epithelia. Much greater reactivity occurs in the olfactory and VNO nerve bundles. By E15 the degree of reactivity increases, and the pattern of Neu 4 reactivity in the nasal cavity and surrounding tissues becomes virtually identical to that of 

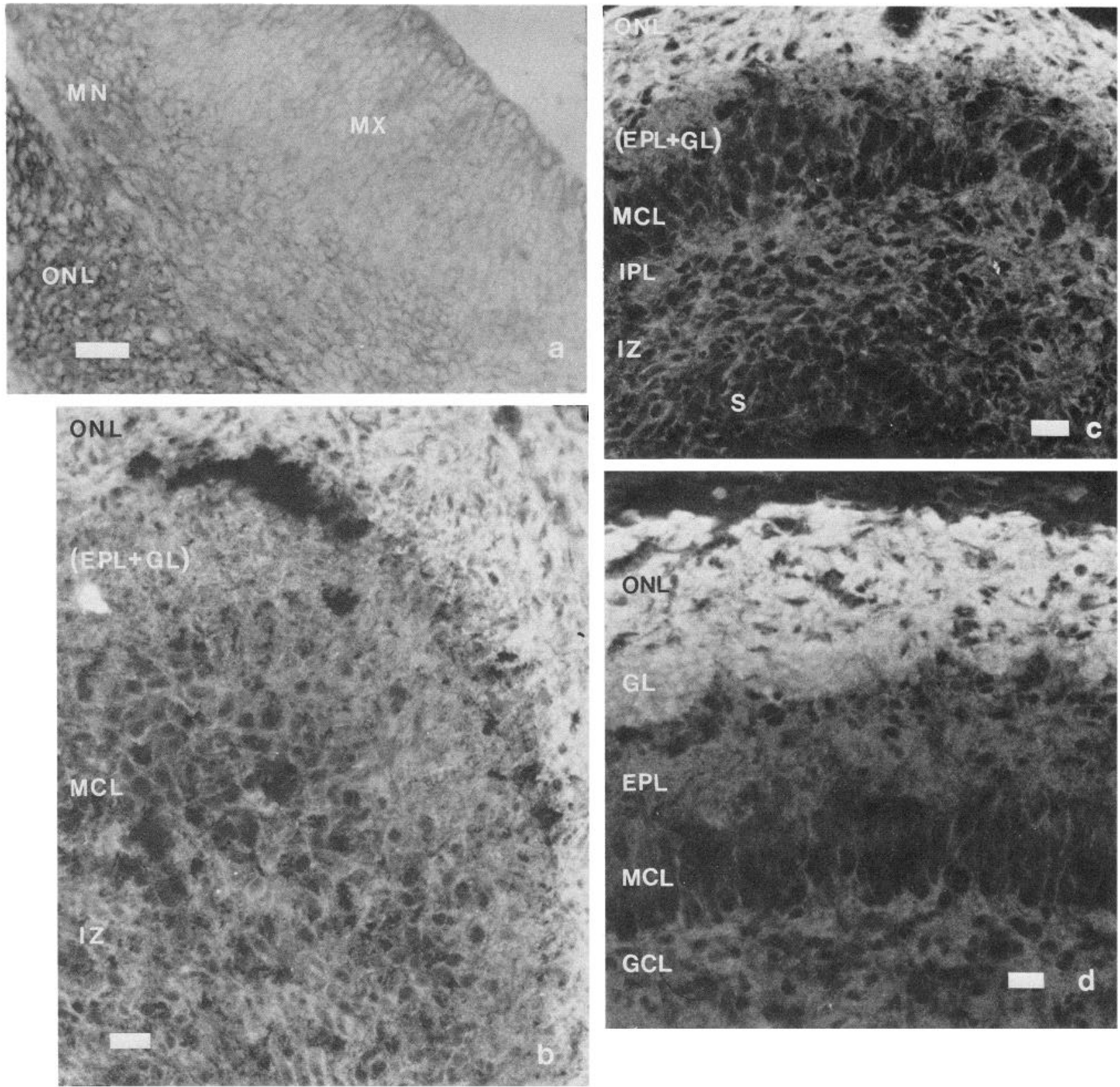

Figure 8. Neu 5 reactivity in the olfactory bulb. $a$, E15. Immunoperoxidase preparation of the medioventral wall of the anterior cerebral vesicle, the presumptive bulbar region, Reactivity occurs on virtually all cells. The radial and more random cell orientations of the matrix $(M X)$ and mantle $(M N)$ regions, respectively, are apparent. The most intense reactivity occurs in the developing ONL. $b-d$, Immunofluorescent preparations. $b$, E18. The intensely reactive ONL is apparent. The primitive EPL+GL $(E P L+G L), \mathrm{MCL}$, and randomly oriented cells of the IZ can also be seen. $c$, E19. The bulb has undergone considerable maturation from E18, although the GL and GCL have not yet formed. The IPL is present in patches. Varying degrees of pericellular and fibrous reactivity occur in each of the remaining layers, with the subependymal layer $(S)$ showing the least. $d$, E22. GL, EPL, and GCL are now distinct. Reactivity of individual glomeruli in the GL is slightly decreased relative to the ONL. The patches of IPL seen in $c$ are not obvious in this particular micrograph. Scale bars, $40 \mu \mathrm{m}(a)$ and $20 \mu \mathrm{m}(b-d)$.

Neu 9 (Fig. 13a). In these structures it remains so for the rest of embryonic development.

This striking degree of similarity, however, is not universal. In other regions besides the nasal cavity Neu 4 reactivity patterns begin to diverge somewhat from those of Neu 9 at later stages of embryogenesis. In the VNO a possibly less intense reactivity to Neu 4 relative to that of Neu 9 occurs after E18. Such decreased Neu 4 reactivity has been noted previously in the VNO of adult rats (Morgan, 1986). In the olfactory bulb (Fig. 13b), fewer mitral cells appear reactive to Neu 4 than to Neu 9, and Neu 4 may show greater reactivity of the EPL. Finally, experiments using FITC- and rhodamine-conjugated immunoglobulin mixtures as secondary antibodies show that sites reactive to either 1 of the 2 Mabs are not blocked by pretreatment with the other Mab. Nevertheless, in all other respects Neu 4 reactivity appears very similar to that of Neu 9 . 


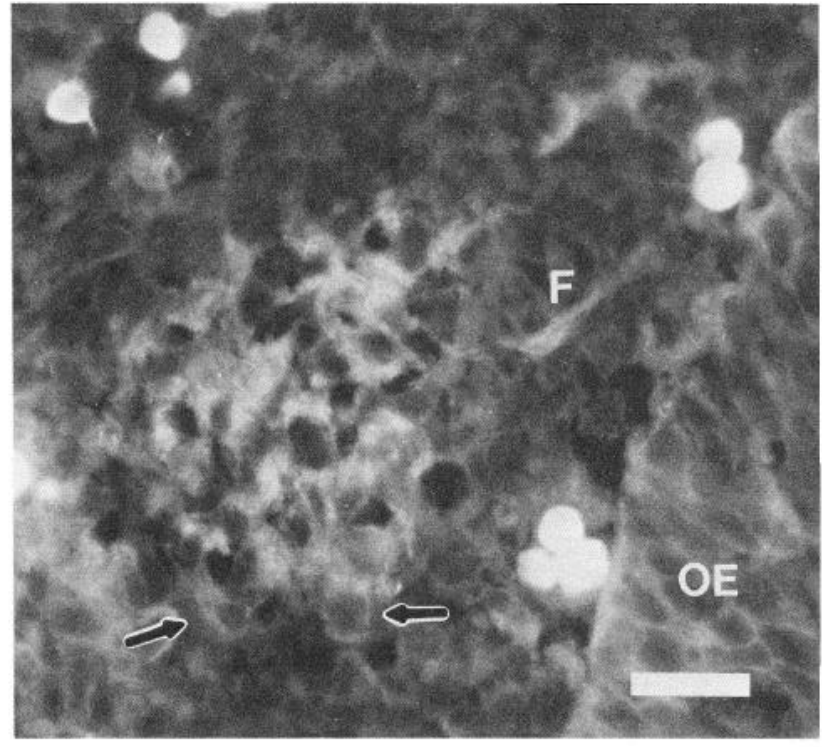

Figure 9. Initial Neu 9 immunoreactivity in the developing olfactory nerve at E13. Reactive fibers $(F)$ can be seen joining the olfactory nerve from the olfactory epithelium $(O E)$. As with Neu 5, Neu 9 reactivity occurs on cells associated with the olfactory nerve (e.g., arrows). Scale bar, $20 \mu \mathrm{m}$.

\section{Explant cultures}

Individual olfactory axons (particularly their growth cones) in situ or in the $50 \mu \mathrm{m}$ Vibratome sections used in electron microscopic immunoperoxidase procedures are relatively inaccessible to antibodies, which are large molecules and penetrate tissues rather poorly. Because of this, we used explant cultures to confirm the distribution of Mab reactivity on axons and growth cones described above. The explants were small and the axons and growth cones were exposed, thus permitting easy access of the antibodies to the axonal surfaces. The light microscopic observation of tissue cultures stained with Mabs Neu 4, Neu 5, and Neu 9 showed heavy staining of axons (Fig. 14, $a$ $c$ ). No such staining could be observed when a polyclonal antibody to the olfactory marker protein OMP was used (not shown). Confirmation of the surface staining was obtained by making thin sections of these axon bundles and examining them with the electron microscope (not shown).

From the cultures grown on the gold grids and examined as whole mounts after critical-point drying, we observed that all $3 \mathrm{Neu}$ Mabs are immunoreactive with membranes of olfactory receptor axons along their entire length to their terminations in the growth cones (Fig. 14,d-f).

\section{Nonnasal and nonolfactory reactivity}

Components reactive to these Mabs are not confined to nasal and VNO structures. Strong fibrous and pericellular reactivities to all 3 occur throughout the brain and cranial nerves although regional differences do occur. In addition, Neu 5 pericellular reactivity occurs throughout the eye; Neu 4 and Neu 9 stain only the outermost cell layer. All 3 Mabs also show strong pericellular reactivity with the choroid plexus. Staining also occurs in the basal regions of nasal glandular material (i.e., the maxillary sinus and septal glands). No reactivity occurs in the heart, lung, kidney, or liver.

Nonspecific reactivity begins to appear in mesenchymal, perivascular, and pericartilagenous tissues at E17 or E18 (e.g., see Fig. $5 b$ ). This is due to cross-reactivity of the anti-mouse secondary antibodies with rat tissue components: pretreatment of the FITC-goat anti-mouse and biotinylated anti-mouse secondary antibodies with $10 \%$ normal rat serum for $1 \mathrm{hr}$ (Chiu et al., 1986) eliminated this reactivity completely.

\section{Western blots}

When Western blots of homogenates of adult olfactory epithelium were performed, the Mab Neu 5 reacted with a major
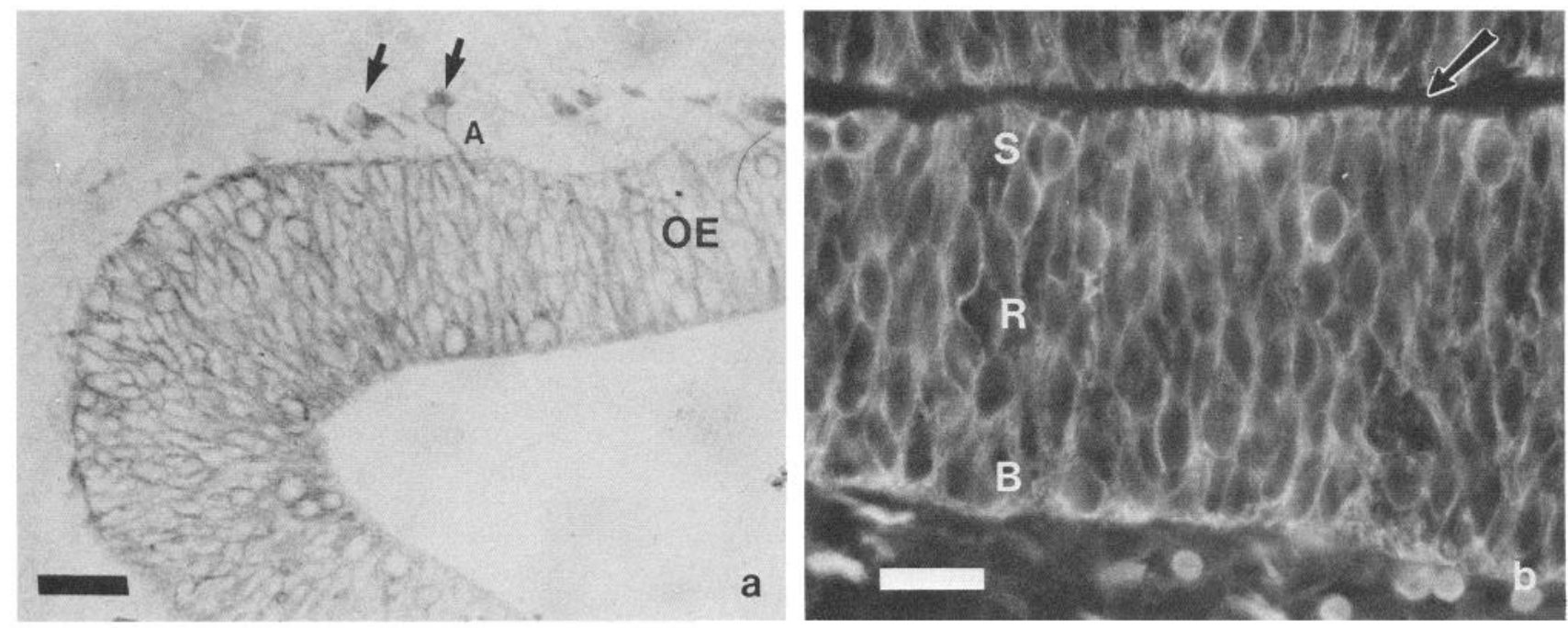

Figure 10. Neu 9 reactivity in the nasal olfactory epithelium $(O E), a, \mathrm{E} 14$, immunoperoxidase. Ubiquitous pericellular reactivity is apparent. Axonal reactivity $(A)$ can be seen as receptor cell axons emerge from the epithelium. Pericellular reactivity can also be seen on cells associated with reactive axons in the lamina propria (arrows). $b$, E17, immunofluorescence. A thickening of reactive material can be seen at the luminal surface in the region indicated by the arrow, but dendritic knobs are not stained. Pericellular reactivity occurs ubiquitously throughout the epithelium, including supporting $(S)$, receptor $(R)$, and basal $(B)$ cells. These features are maintained throughout the remainder of embryogenesis. Scale bars, $40 \mu \mathrm{m}(a)$ and $20 \mu \mathrm{m}(b)$. 

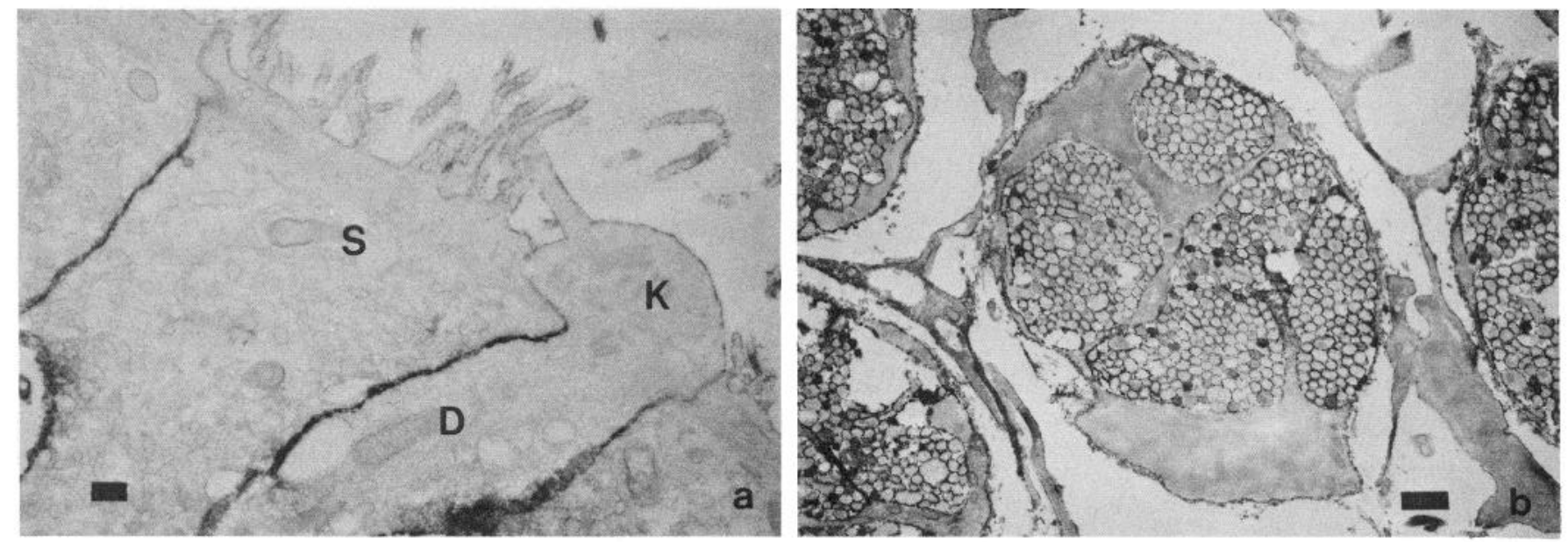

Figure 11. Electron micrographs of Neu 9 immunoperoxidase reactivity at E19. a, Olfactory epithelium. Strong reactivity is confined to the lateral surfaces of olfactory receptor cell dendrites $(D)$ and supporting cells $(S)$. Strong reactivity does not occur on the luminal surfaces of supporting cells or receptor cell dendritic knobs $(K)$. $b$, Olfactory nerve. Reactivity occurs on the surface of individual axons, axon bundles, and ensheathing cells. As with Neu 5 axoplasmic reactivity occurs in a few axons (see text, Fig. $3 b$ ). Scale bars, $1 \mu \mathrm{m}$.

component having a $M_{r}$ of $210 \mathrm{kDa}$ and a minor component at $150 \mathrm{kDa}$ (Fig. 15a). Adult olfactory bulb and cerebral cortex showed a major band at $125 \mathrm{kDa}$, as well as minor bands at 210 and $150 \mathrm{kDa}$. The $210 \mathrm{kDa}$ band was much more prominent in the bulb than in the cortex. The $150 \mathrm{kDa}$ band was very faint, especially in the bulb. Other parts of the nervous system expressed only the $125 \mathrm{kDa}$ band.

Western blots of Neu 5 reactivity in whole-brain homogenates at different times of development showed that the 2 higher bands were prominent in the embryonic and neonatal tissues but that during development there was a progressive increase of the 125 $\mathrm{kDa}$ band and a decrease of the $210 \mathrm{kDa}$ band (Fig. 15b). This change was especially noticeable after P3 and P11.

Because the distribution of these apparent molecular weights and the developmentally related shift in this distribution were similar to those of the neural cell adhesion molecule N-CAMapproximately 120,140 , and $180 \mathrm{kDa}$ and an embryonic form at 200-250 kDa (Chuong and Edelman, 1984; Lyles et al., 1984)Western blots of membrane fractions of P23 rat brains were reacted in parallel with Neu 5 and various monoclonal and polyclonal antibodies to rat N-CAMs. When these blots were prepared from $10 \%$ acrylamide gels, the $M_{r}$ 's of Neu 5-reactive material were 160 and $125-130 \mathrm{kDa}$. In those blots Neu 5 and one of the anti-rat N-CAM Mabs (3F4.18) reacted with bands of exactly the same $M_{r}$ 's. However, because the higher molecular weight bands were not well resolved at this acrylamide concentration, new blots were prepared from $7.5 \%$ gels. In those blots Neu 5 and 3F4.18 both reacted with bands having $M_{r}$ 's of 160 , and 210 , as well as a broad band at $225-250 \mathrm{kDa}$ (Fig. 15c). The other anti-N-CAMs (Mab 3G6.41 and polyclonal 161) show similar bands at 160 and $210 \mathrm{kDa}$ but only a narrow band at $225 \mathrm{kDa}$. The differences between these particular $M_{r}$ 's and those found in our initial blots likely reflect the different acrylamide concentrations used in the 2 studies. Mobility of heavily glycosylated proteins such as N-CAM is well known to be greatly affected by acrylamide concentration differences; the molecularweight standards used were not so heavily glycosylated.

We were unable to obtain immunoblots for Neu 4 or Neu 9 run on the same material. The reasons for this are uncertain but may be due to epitope alteration or reduced antigenicity under the conditions of the SDS-PAGE (although immunoprecipitation procedures also yielded negative results) or to insufficient antigenic material in the gels.

\section{Discussion}

The studies reported in this paper have described the developmental expression in rats of reactivities to $3 \mathrm{Mabs}$ generated against adult rat olfactory tissue. Each of these Mabs reacts with cell-surface moieties. For Neu 5 the similarity of immunoblots with those obtained using several antibodies directed against rat N-CAMs, despite the differences in the $M_{r}$ 's obtained in these particular blots and those reported previously by others $(120$, 140, 180, and 200-250; e.g., Chuong and Edelman, 1984; Lyles et al., 1984; Williams et al., 1985), strongly suggests that Neu 5 is directed against N-CAM moieties. In addition, the developmentally related shift in the apparent molecular-weight distribution of Neu 5-reactive material toward lower $M$, bands in the brain, the continued expression of higher-molecular-weight embryonic Neu 5 bands in the adult olfactory epithelium and bulb, and the strikingly similar immunohistochemical reactivity patterns obtained with Neu 5 (and anti-N-CAMs) in the present study compared with those observed for anti-N-CAM in mice (Chuong and Edelman, 1984) and rats (Lyles et al., 1984) provide further strong evidence that $\mathrm{Neu} 5$ is directed against $\mathrm{N}-\mathrm{CAM}$ moieties.

Despite the similarities, however, differences in reactivity patterns between our own and previous studies do exist. In addition to differences noted in the Results, Neu 5 also shows reactivity in all layers of the olfactory bulb of young adult rats and fails to show the decreased immunoreactivity in cerebral cortex, cerebellum, or brain stem late in development (results of studies carried out at P29 not discussed in the present paper) or in adults (Hempstead and Morgan, 1985a) described for anti-NCAM antibodies by Daniloff et al. (1986). Neu 5 also reacts with some non-neural tissue. These differences likely reflect slight variations in the components involved, and further studies are needed to resolve them as well as the differences in apparent molecular weights between the present and previous studies. 

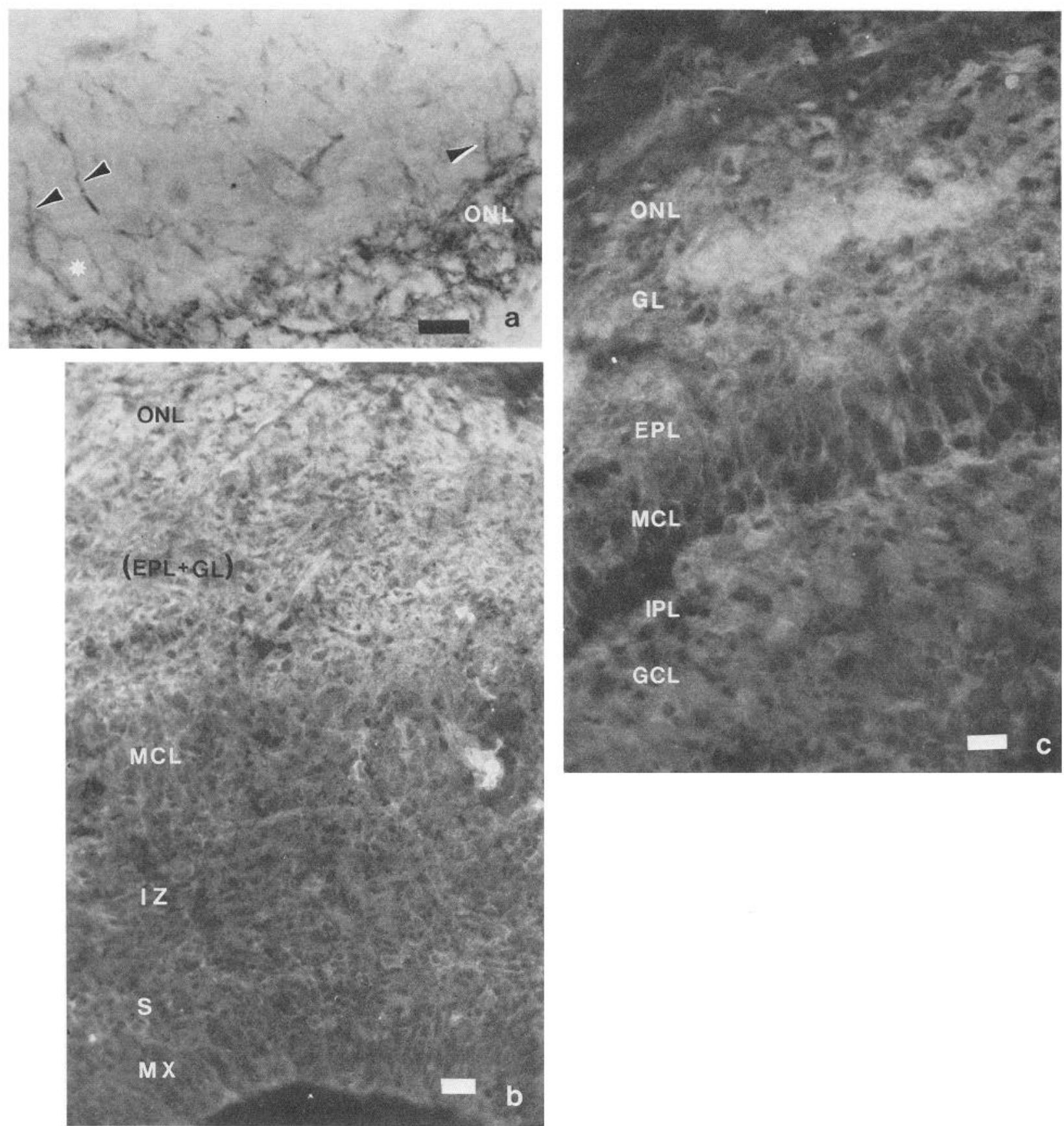

Figure 12. Neu 9 reactivity in the developing olfactory bulb. $a$, E15. Immunoperoxidase preparation of the presumptive bulbar region in the anterior cerebral vesicle. Reactivity occurs in the ONL as well as on axons growing into the bulb from the ONL (arrows). Neu 9-reactive cells can also be seen within the ONL (star). b, E18, immunofluorescence. The ONL is still the most intensely reactive region. Fibrous and pericellular reactivity begin to increase, especially in the primitive (EPL+GL). No reactivity occurs in the matrix region $(M X) . c$, E22, immunofluorescence. Enhanced reactivity is apparent in the glomeruli of the GL. Fibrous and pericellular reactivity occur on cells in the other layers as well. Pericellular reactivity is most pronounced in the MCL. Subependymal layer, which shows no reactivity, is not pictured. Scale bars, $20 \mu \mathrm{m}$.

Especially interesting among our biochemical findings is the presence of the high-molecular-weight, $210 \mathrm{kDa}$, component of the Neu 5 antigen in adult olfactory epithelium and bulb. Whole brain, in contrast to these olfactory structures, shows a progressive loss of the $210 \mathrm{kDa}$ component with development. Presence of this $210 \mathrm{kDa}$ embryonic component in the adult olfactory epithelium is consistent with the continued proliferation and turnover in adults of olfactory receptor neurons (Moulton, 1974; Graziadei and Monti Graziadei, 1978). Its presence in the adult bulb very likely reflects the presence of olfactory receptor cell axons in the ONL and GL. Neurons intrinsic to the bulb itself are likely to be expressing the lowermolecular-weight adult forms. Persistence of high levels of a high-molecular-weight component in the olfactory epithelium and bulb relative to other neural structures has also been noted by Chuong and Edelman (1984).

The identity of Neu 9 and Neu 4 antigens is unknown. Their immunohistochemical reactivity patterns do not correspond with 

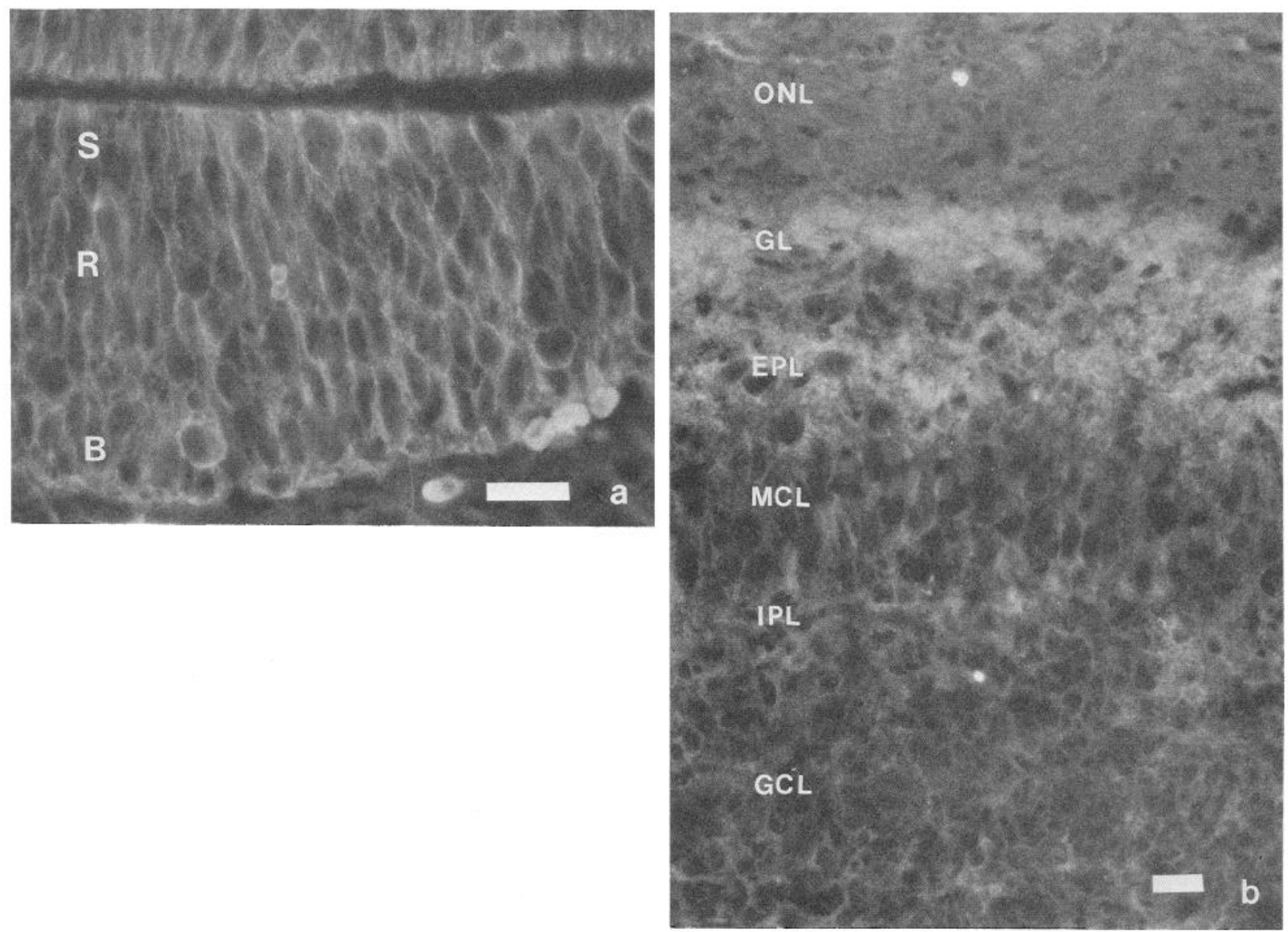

Figure 13. Neu 4, immunofluorescent preparations. $a$, E17 olfactory epithelium. Compare with Neu 9 reactivity in Figure $10 b . b$, E22 olfactory bulb. Compare with Neu 9 reactivity in Figure $12 c$. The primary difference appears to be a slightly greater Neu 4 than Neu 9 reactivity in the EPL. Mitral cell pericellular Neu 4 reactivity may be less as well. Labeling as in Figures $10 b$ and $12 c$, respectively. Scale bars, $20 \mu \mathrm{m}$.

those of other well-known surface molecules such as N-CAM or Ng-CAM (Grumet et al., 1984).

Results of our immunohistochemical observations of the olfactory epithelium along with related findings of other researchers are summarized in Table 1. Reactivities to 2 of our Mabs, Neu 5 and Neu 9, first appear on axons and associated cells growing through the mesenchyme from the olfactory epithelium at E13. This is the earliest time at which olfactory axons can be demonstrated in the mesenchyme (Farbman and Squinto, 1985). This precocious axonal reactivity occurs 1 or $3 \mathrm{~d}$ (Neu 9 and Neu 5, respectively) before the appearance of reactivity on neuronal cell bodies and is thus consistent with Neu 5 and Neu 9 antigens having roles in axonal outgrowth. Reactivity to the third Mab, Neu 4, is not seen until E14, but its initial appearance occurs simultaneously on cells throughout the epithelium, as well as along the entire axon and on associated cells.

Several other notable differences between the reactivity pattern of Neu 5 and those of Neu 4 and Neu 9 are also summarized in Table 1. The first is that in the nasal cavity Neu 5 reacts with olfactory receptor and basal cells only, while Neu 4 and Neu 9 react with supporting cells as well. Neu 4 and Neu 9 supporting cell reactivity was not observed in a previous study in normal adult rats (Hempstead and Morgan, 1985a). However, following olfactory bulbectomy, reactivity to Neu 4 and Neu 9 was observed among a class of cells that had the morphological characteristics of supporting cells but that were located in the ol- factory receptor cell layer of regenerating, ipsilateral epithelia (Hempstead and Morgan, 1985b). It may be that such cells are more prevalent or have a more apical location in developing tissue. The enhanced clarity and duration of fluorescence achieved using $\mathrm{NaI}$ in the present study may also have made these Neu 4- and Neu 9-reactive cells more apparent, although we do obtain a similar pattern with immunoperoxidase staining as well. Interestingly, this apical Neu 4 and Neu 9 pericellular reactivity was observed from the earliest times. Given that embryonic mitotic activity in the olfactory epithelium occurs at the luminal surface (Smart, 1971), Neu 4 and Neu 9 would also appear to be reactive with very immature, perhaps even mitotic, cells.

A second difference in the reactivity patterns is the fact that initial Neu 4 and Neu 9 pericellular reactivities occur uniformly, if faintly, on all cells. In contrast, Neu 5 pericellular reactivity first appears on single cells or on small groups of cells in the nasal and VNO epithelia. Interestingly, a clustering of early olfactory receptor cells has also been observed at the ultrastructural level in mice (Cuschieri and Bannister, 1975b). These clusters subsequently disappeared as increasing numbers of differentiating receptor cells appeared. Early clustering of receptor cells reactive to the $2 \mathrm{~B} 8 \mathrm{Mab}$ in rat has also been reported (Allen and Akeson, 1985). Neu 5-reactive cells are also more numerous in the epithelium on the medial (septal) side of the nasal cavity.

Finally, Neu 5 differs from Neu 4 and Neu 9 in its ability to 

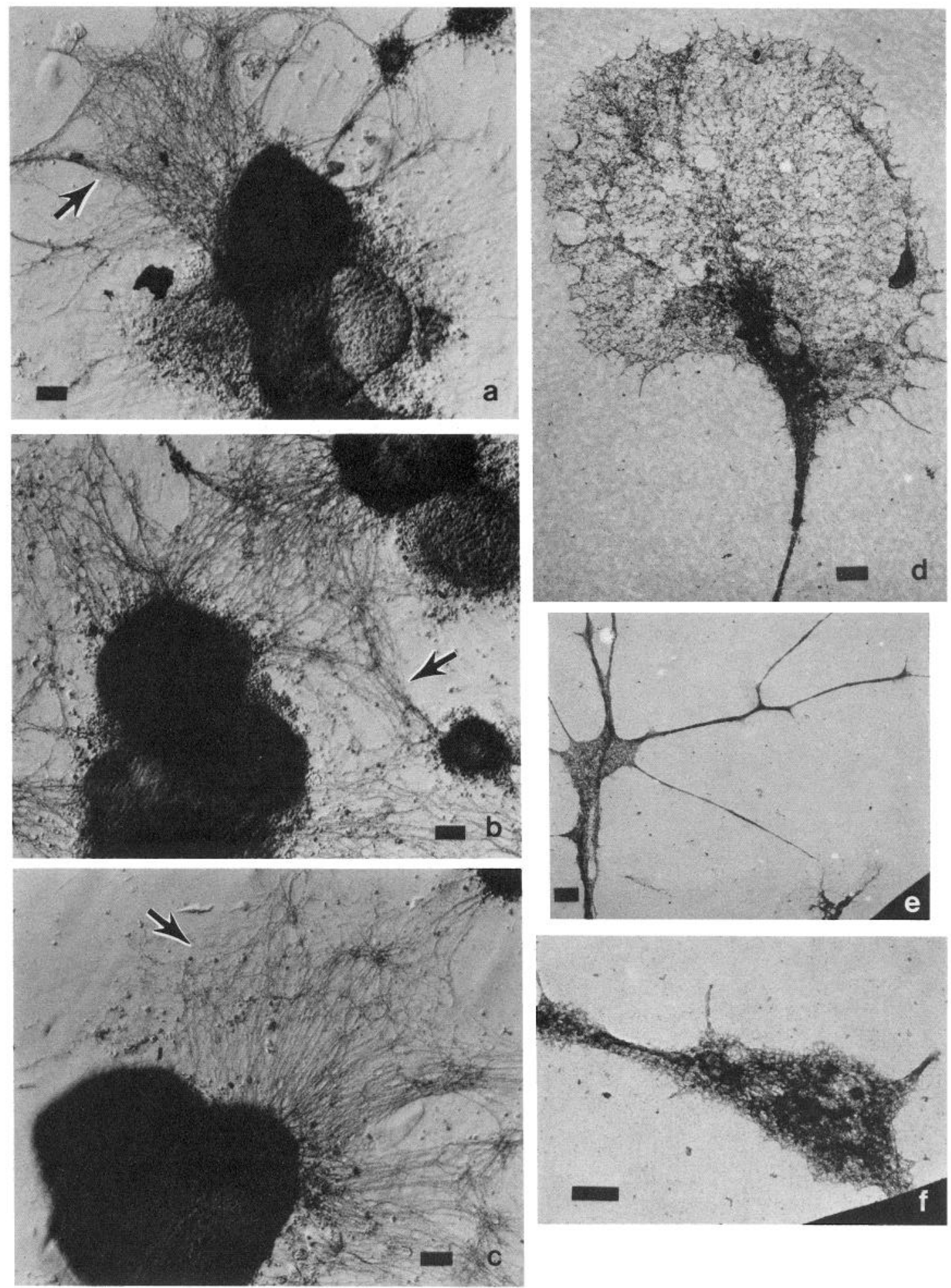

Figure 14. $a-c$, Explant cultures of nasal olfactory epithelium labeled with Neu 4, Neu 5, and Neu 9, respectively, and stained by immunoperoxidase procedures. Reaction product is apparent on outgrowing fibers (arrows) but does not occur on non-neural cells growing on the substratum (especially apparent in $a$ ). Membrane-associated reactivity is also not seen in control cultures labeled with antibodies to OMP, a cytoplasmic protein (not shown). $d-f$, Electron micrographs of growth cone surfaces labeled with Neu 4, Neu 5, and Neu 9, respectively. These were prepared from explant cultures grown on gold grids and subjected to critical-point drying. Scale bars, $50 \mu \mathrm{m}(a-c)$ and $1 \mu \mathrm{m}(d-f)$.

react with dendritic knobs. Ultrastructurally, Neu 4 and Neu 9 reactivities, with only few exceptions, are confined to the sides of dendrites and supporting cells up to the level of the apical tight junctions but are absent from their luminal surfaces. Neu
5 reacts with the dendritic surfaces in their entirety.

The temporal changes that we observe in the reactivity patterns of these Mabs correlate well with other developmental events in the olfactory epithelium as illustrated in Table 1. 
Table 1. Summary of our observations on the developmental expression of Neu 4, Neu 5, and Neu 9 reactivities in the nasal olfactory epithelium and olfactory nerves correlated with findings of others on olfactory epithelium development

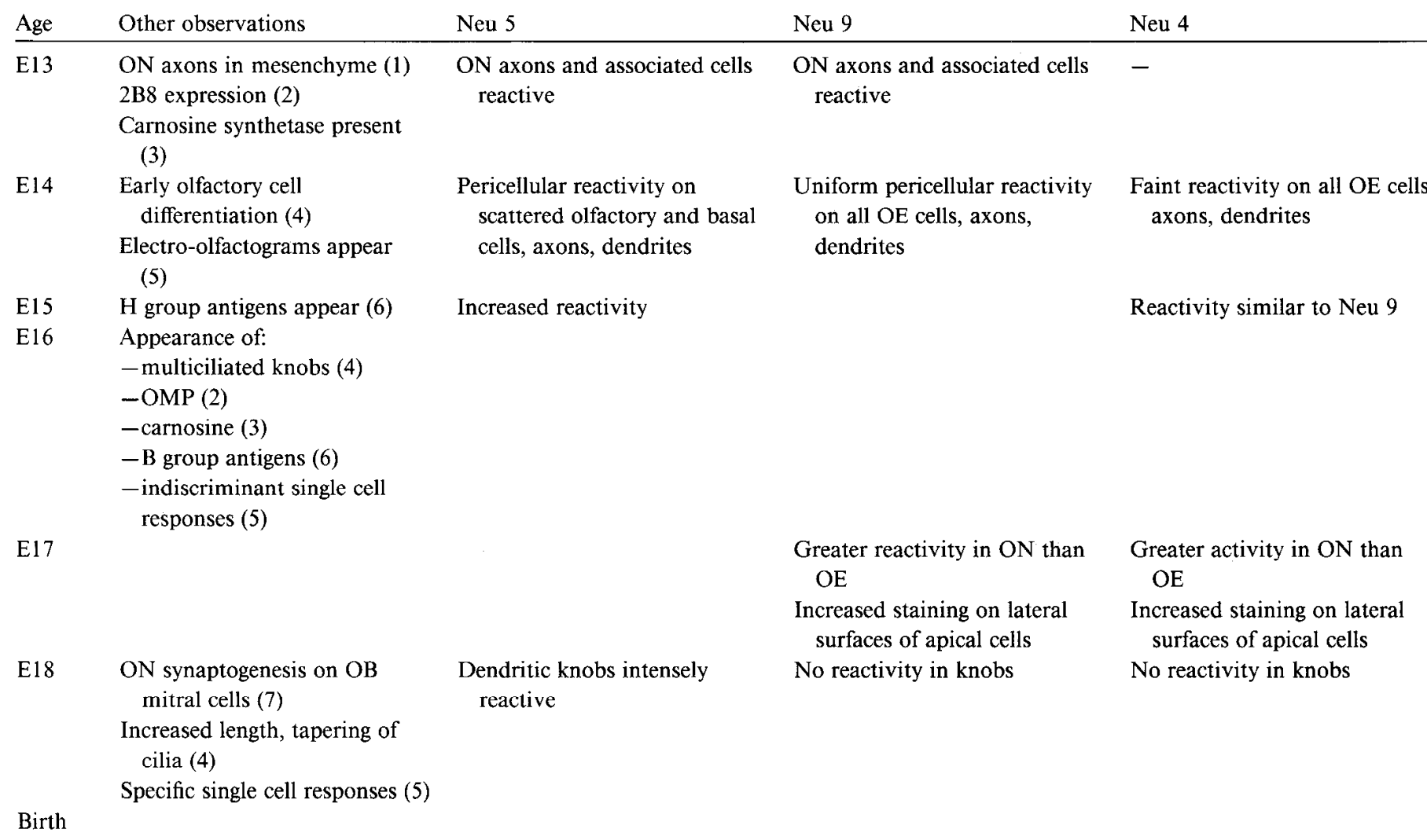

Numbers in parentheses refer to references as follows: 1, Farbman and Squinto (1985); 2, Allen and Akeson (1985); 3, Margolis et al. (1985); 4, Menco and Farbman

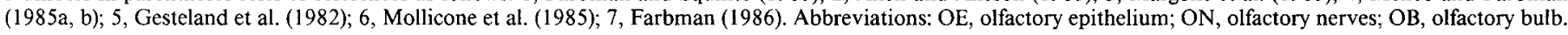

Briefly, E14, when Neu 5 and Neu 9 reactivities first appear in the olfactory epithelium, is also the age at which the epithelium begins to show olfactory characteristics such as the layering of nuclei and the presence of knob-shaped dendritic structures (Menco and Farbman, 1985a, b), when massive changes in tight junction morphology occur in the epithelium (Menco, 1988), and when electro-olfactograms are first measurable (Gesteland et al., 1982). At the developmentally equivalent age in mice, the number of apical mitotic figures declines dramatically as well (Smart, 1971). The succeeding days are marked by the appearance of Neu 4 reactivity and increased reactivity to all 3 Mabs. During this period the appearance of secondary cilia along with increases in their number and length (Menco and Farbman, $1985 \mathrm{a}, \mathrm{b})$, the appearance of the $\mathrm{H}$ and $\mathrm{B}$ blood group antigens (Mollicone et al., 1985) and of OMP (Allen and Akeson, 1985), and the onset of indiscriminant single responses to odorants (Gesteland et al., 1982) have been observed. A developmentally related decline in the reactivity of the $2 \mathrm{~B} 8 \mathrm{Mab}$ in the olfactory epithelium has also been observed during this time (Allen and Akeson, 1985).

A second period of major change in the olfactory epithelium has been shown to occur at about E18, when we see a pronounced increase in Neu 5 dendritic knob reactivity. It is at this time that dendritic knobs take on a more mature appearance, with a dramatic increase in length and degree of tapering of the olfactory cilia (Menco and Farbman, 1985a, b). This is also the time of initial synaptogenesis between receptor cell axons and the secondary olfactory neurons within the olfactory bulb (Farb- man, 1986). A trophic correlation between these events has been suggested (Farbman and Margolis, 1980; Chuah and Farbman, 1984; Chuah et al., 1985; see also Cuschieri and Bannister, 1975b). Odorant-specific single-cell responses are also first demonstrable at E19 (Gesteland et al., 1982).

Results of our observations of the developmental expression of the 3 Mabs in the VNO are summarized in Table 2. The $\mathrm{VNO}$ is thought to respond to a different range of odorants than does the nasal olfactory epithelium, possibly based on relative volatility (Wysocki et al., 1980; Rehn et al., 1982; but also see O'Connell and Meredith, 1984). It may be especially important in mammalian reproduction and pheromone detection (Winans and Powers, 1977; Meredith et al., 1980).

Initially, the VNO is quite similar to the nasal olfactory epithelium, in both the times of first appcarance of reactivity (E14 for Neu 5 and Neu 9 and E15 for Neu 4) and in its reactivity patterns. However, within a few days the VNO olfactory epithelium development seems to fall behind that of the olfactory epithelium proper. For Neu 5 there is a 2 d delay relative to the nasal olfactory epithelium in the progression from scattered receptor cell reactivity to a more uniform distribution. For Neu 4 and Neu 9, VNO pericellular and dendritic reactivity remains lower than that in the nasal cavity throughout embryogenesis. Such an apparent developmental delay has been noted before, at the light microscope level in rats (Garrosa et al., 1986) and at the ultrastructural level in hamsters (Taniguchi et al., 1982a, b), as well as in the onset of OMP expression (Farbman and Margolis, 1980; Allen and Akeson, 1985). 


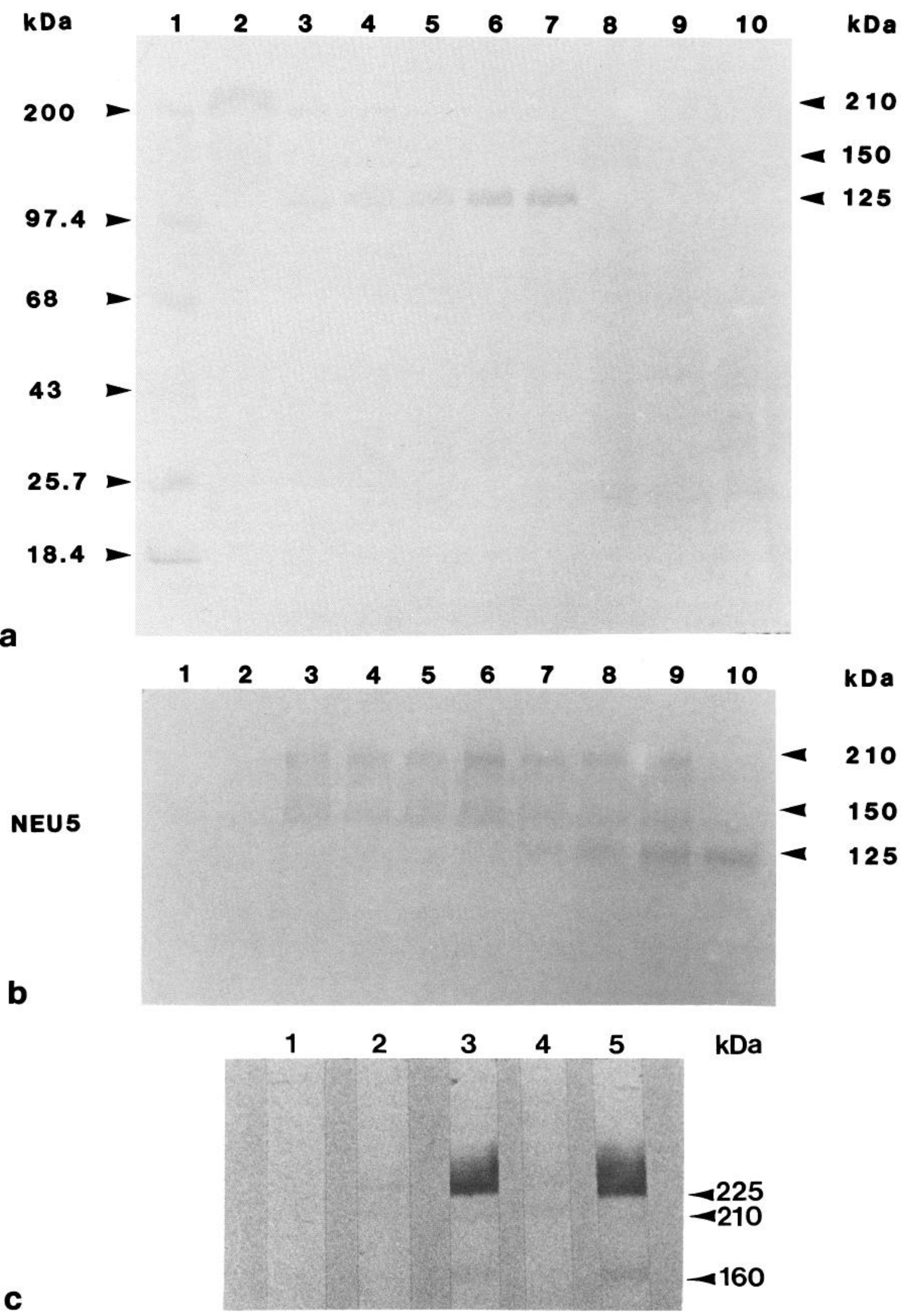

Figure 15. Immunoblots of Neu 5-reactive moieties. $a$, Homogenates of adult rat tissues. The olfactory epithelium (lane 2) shows a prominent band of immunoreactivity at $210 \mathrm{kDa}$ and a minor band at $150 \mathrm{kDa}$. The olfactory bulb (lane 3 ) and cerebral cortex (lane 4 ) show both bands as well as a major band at $125 \mathrm{kDa}$. The $150 \mathrm{kDa}$ is very faint. All other brain regions show reactivity only at $125 \mathrm{kDa}$ (cerebellum, lane 5 ; brain stem, lane 6; spinal cord, lane 7). No overt Neu 5 reactivity can be seen in non-neural tissues (liver, lane 8; adrenal glands, lane 9; kidney, lane 10). Test samples are in lane 1. b. Homogenates of whole rat brain at various ages (E13, lane 1; E15, lane 2; E17, lane 3; E20, lane 4; P1, lane 5; 


\begin{tabular}{|c|c|c|c|c|}
\hline Age & Other observations & Neu 5 & Neu 9 & Neu 4 \\
\hline E13 & $2 \mathrm{~B} 8$ in most cells and axons & & & \\
\hline E14 & & $\begin{array}{l}\text { Pericellular reactivity on } \\
\text { scattered cells and processes } \\
\text { in presumptive OE and RFE }\end{array}$ & $\begin{array}{l}\text { Uniform pericellular reactivity } \\
\text { throughout the VNO }\end{array}$ & $\begin{array}{l}\text { Faint reactivity on all cells and } \\
\text { processes }\end{array}$ \\
\hline E15 & & & & Reactivity similar to Neu 9 \\
\hline E16 & $\begin{array}{l}\text { RFE and OE distinguishable } \\
\text { on basis of cell number }\end{array}$ & $\begin{array}{l}\text { Continual decrease in number } \\
\text { of reactive RFE cells and } \\
\text { loss of reactive RFE } \\
\text { processes until E19 }\end{array}$ & $\begin{array}{l}\text { Large decline in staining } \\
\text { intensities }\end{array}$ & $\longrightarrow$ \\
\hline E18 & & $\begin{array}{l}\text { Uniform reactivity in } \mathrm{OE} \\
\text { olfactory, basal cells, axons, } \\
\text { dendrites } \\
\text { Staining intensity less than in } \\
\text { nasal cavity }\end{array}$ & $\begin{array}{l}\text { Very low levels of reactivities } \\
\text { in OE, RFE } \\
\text { In region of VNO axonal } \\
\text { reactivities remain strong }\end{array}$ & $\begin{array}{l}\longrightarrow \\
\longrightarrow\end{array}$ \\
\hline E19 & $\begin{array}{l}\text { Low levels of OMP appear (1) } \\
\text { RFE width reduced to } 1-2 \\
\text { cells }\end{array}$ & $\begin{array}{l}\text { Only a few reactive RFE cells } \\
\text { remain }\end{array}$ & $\begin{array}{l}\text { Loss of apical pericellular } \\
\text { reactivity except in } \\
\text { transition zone } \\
\text { RFE cells no longer reactive } \\
\text { Decreased reactivity in larger, } \\
\text { dorsal nerves of septum }\end{array}$ & $\longrightarrow$ \\
\hline
\end{tabular}

1. Allen and Akeson (1985). Abbreviations: OE, olfactory epithelium; RFE, receptor-free epithelium.

However, while these differences may simply represent a delay in development of the VNO olfactory epithelium, they may also reflect a divergence of the VNO developmental pattcrn from that of the olfactory epithelium proper as well. This would seem especially true with Neu 4 and Neu 9, as they show an absolute as well as relative decline in the degree of reactivity with development, especially after E16. Further support for a developmental divergence comes from the different patterns of morphogenesis and reactivities to our Mabs followed by the 2 VNO epithelia compared with those of the nasal cavily. The nasal olfactory and respiratory epithelia can be readily distinguished from each other as early as E13, shortly after the formation of the nasal cavity. In contrast, the olfactory and receptor-free epithelia of the VNO initially appear very similar to each other in both their morphologies and their reactivity patterns. They become distinguishable as the progressive decline in cell number and loss of reactive cells and cell processes in the receptor-free epithelia and maturation of the olfactory epithelia proceed during embryogenesis (see Fig. 6; also Garrosa et al., 1986). Finally, autoradiographic studies in both mice (Hinds, 1968a, b) and rats (Bayer, 1983) have demonstrated that neurons of the accessory olfactory bulb, the target of the VNO receptor cell neurons, are generated and organized prior to those of the corresponding populations of the main olfactory bulb. Although possible, it seems somewhat unlikely that this would occur if overall VNO development were slower than that of the olfactory epithelium proper.

The structures of the VNO and nasal olfactory epithelia in mature animals differ sufficiently to allow for a divergence rather than, or in addition to, a simple delay in development. Differences include the precise species-dependent location of cilia and microvilli on supporting versus olfactory cells (see Breipohl et al., 1982; Naguro and Breipohl, 1982), the location of mitotic cells (Cuschieri and Bannister, 1975a; Barber and Raisman, 1978), the structure of receptor cell dendrites (e.g., Taniguchi et al., 1982b; Kratzing, 1986), histochemistry (Cuschieri, 1974; Mendoza and Breipohl, 1983; Taniguchi et al., 1986), and immunohistochemistry (Mori, 1987). The differences in reactivity patterns of our Mabs between the VNO and nasal olfactory epithelia would reflect these structural differences.

Within the developing olfactory bulb reactivity to all 3 Mabs also appears early, by at least El4. Neu 5 reactivity is ubiquitously distributed throughout the bulb, including the proliferative regions of the matrix and subcpendymal laycrs. As such, Neu 5 resembles a general membrane marker for the bulb, showing patterns of morphogenesis and subpopulation differentiation that closely resemble those described for rats (Bayer, 1983) and mice (Hinds, 1968a, b, 1972a). Nevertheless, layer-specific differences in intensity of Neu 5 reactivity do occur, perhaps reflecting differences in reactive fiber density. development. $c$, Membrane fractions of P23 rat brains showing the similarity between N-CAMs using several Mabs (3G6.41, lane 2; 3F4.18, lane 3) and polyclonal antibodies (161, lane 4) and Neu 5-reactive material (lane 5). Prominent bands occur at 160 and $225-250 \mathrm{kDa}$, and a fainter band appears at $210 \mathrm{kDa}$. In lane 1, PBS was used in place of an antibody. The varying labeling intensities of the bands obtained with the 3 antiN-CAMs likely reflect affinity differences of these antibodies for the N-CAM subclasses (see Williams et al., 1985). 
An intriguing observation of our study is the enhanced reactivity to Neu 4 and Neu 9 seen in the emerging GL after the onset of synaptogenesis at E18 (Farbman, 1986). With Neu 5 (Fig. $8 d$ ), GL reactivity is intermediate between that of the ONL and that of the EPL, as might be expected with a simple intermingling of fibers from each region within the GL. With Neu 4 and Neu 9, however (Figs. $14 b$ and $13 c$, respectively), reactivity is clearly enhanced. This enhancement may reflect a simple intermingling of reactive fibers. However, given the degree of enhancement and the fact that it is not seen with Neu 5, the possibility also exists that the interaction of olfactory receptor axons and their postsynaptic elements within the GL may have resulted in the heightened expression within the GL of some surface component reactive with these Mabs.

The early presence of olfactory nerve fibers at the bulb is also apparent with our 3 Mabs. Large numbers of reactive fibers can be seen growing around the developing bulb as early as E14, and by $\mathrm{E} 15$ some deeply penetrating $\mathrm{Neu} 4$ - and Neu 9-reactive axons can be seen. This early penetration of the bulb by olfactory axons has been described both in rats (Monti Graziadei et al., 1980) and, at a comparable age, in mice (Hinds, 1972a, b). Despite the early presence of receptor cell axons in and around the bulb, however, synaptogenesis has not been reported to occur until E18 in rats (Farbman, 1986) or E15 in mice (Hinds and Hinds, 1976). Indeed, in the present study, despite the presence of the few deeply penetrating fibers at E15, there was not a massive ingrowth of axons from the ONL into the underlying mantle layer until after the onset of synaptogenesis, at E18. There is, therefore, a significant delay between the arrival of the olfactory axons and the synaptogenesis within the bulb by these axons. Similar delays have been noted in the innervation of the chick limb bud (Tosney and Landmesser, 1985) and other systems (e.g., see Shatz and Luskin, 1986). In the limb bud outgrowing motor fibers seem to pause at the base of the developing limb before rapidly growing to their specific muscle targets. Tosney and Landmesser speculate that this delay represents a period of decision-making and sorting out of the motor axons within the nerve plexus. That such a process might be occurring between E14 and E18 in the olfactory nerve plexus seems quite likely. Graziadei and Monti Graziadei (1986) have recently noted that in olfactory nerve regeneration and other experimental situations the formation of an olfactory nerve plexus is necessary for successful differentiation of glomeruli. They suggest that some required interaction must be occurring within the plexus between fibers originating from scattered regions of the olfactory epithelium. The $4 \mathrm{~d}$ delay between the arrival of olfactory axons and the onset of synaptogenesis within the bulb would allow time for a similar interaction to occur during development as well. Alternative explanations have to do with the relative maturities of ingrowing fibers and their target cells or with the nature of the environment in which the afferent fibers wait (Shatz and Luskin, 1986).

Finally, all 3 of the Mabs described in this paper are reactive with cells associated with the outgrowing olfactory nerve axons from the earliest time of fiber outgrowth at E13. The presence of such cells in olfactory nerve bundles has been noted by several groups (e.g., Cuschieri and Bannister, 1975a, b; Mendoza et al., 1982; Farbman and Squinto, 1985; Brunjes and Frazier, 1986). In fact, Mendoza et al. (1982) report that migration of these cells from the olfactory epithelium precedes the outgrowth of the receptor cell axons. The identity of these cells is not known. However, it has been suggested that they become the ganglionic neurons of the nervus terminalis (Graziadei and Monti Graziadei, 1978), that they are Schwann cells (Cuschieri and Bannister, 1975b), or that they function as guide cells (Farbman and Squinto, 1985; Farbman and Menco, 1986). The possibility that Schwann cells themselves may function as guide cells has been reviewed recently (Keynes, 1987). What is demonstrated in the present findings is the large number of these reactive cells that seems to accompany the outgrowing fibers all the way to the olfactory bulb. By E14 and E15 an accumulation of these immunoreactive cells can be observed at the leading edge of the olfactory nerve, just below the developing bulb. Later, many reactive cells occur at the junction between the olfactory nerve and the ONL. If these cells were simply performing functions ascribed to Schwann cells, it would seem likely that they would be more uniformly distributed along the developing olfactory nerve bundles.

In conclusion, we have described the developmental expression of immunoreactivity in olfactory tissues to several Mabs directed against the adult olfactory epithelium. One of these, Neu 5, has been shown to react with moieties that closely resemble N-CAM. The role of N-CAM in development has been extensively revicwed (Edclman, 1984, 1985; Rutishauscr, 1984, 1986). The identities of Neu 4- and Neu 9-reactive moieties are not yet known. However, given that these Mabs react with the surfaces of olfactory receptor cells, dendrites, and axons, with cells and processes of the olfactory bulb, and with cells migrating with the olfactory receptor cell axons, that these reactivities appear early in development, and that reactivities to these 2 Mabs appear enhanced in the developing glomeruli of the olfactory bulb, the antigens for these Mabs are also likely to play developmentally significant roles.

\section{References}

Allen, W. K., and R. Akeson (1985) Identification of an olfactory receptor neuron subclass: Cellular and molecular analysis during development. Dev. Biol. 109: 393-401.

Anholt, R. H., S. M. Mumby, D. A. Stoffers, P. R. Girard, J. F. Kuo, and S. H. Snyder (1987) Transduction proteins of olfactory receptor cells: Identification of guanine nucleotide binding proteins and protein kinase C. Biochemistry 26: 788-795.

Barber, P. C., and G. Raisman (1978) Cell division in the vomeronasal organ of the adult mouse. Brain Res. 141:57-66.

Bayer, S. A. (1983) [ $\left.{ }^{3} \mathrm{H}\right]$-thymidine-radiographic studies of neurogenesis in the olfactory bulb. Exp. Brain Res. 50: 329-340.

Blackenbury, R., J.-P. Thiery, U. Rutishauser, and G. M. Edelman (1977) Adhesion among neural cells of the chick embryo. I. An immunological assay for molecules involved in cell-cell binding. J. Biol. Chem. 252: 6835-6840.

Böck, G., M. Hilchenbach, K. Schauenstein, and G. Wick (1985) Photometric analysis of antifading reagents for immunofluorescence with laser and conventional sources. J. Histochem. Cytochem. 33: 699705.

Breipohl, W., K. P. Bhatnagar, and A. Mendoza (1979) Fine structure of the receptor-free epithelium in the vomeronasal organ of the rat. Cell Tissue Res. 200: 383-395.

Breipohl, W., A. S. Mendoza, and F. Miragall (1982) Freeze-fracturing studies on the main and vomeronasal olfactory sensory epithelia in NMRI-mice. In Olfaction and Endocrine Regulation, W. Breipohl, ed., pp. 309-322, Information Retrieval, Ltd., London.

Brunjes, P. C., and L. L. Frazier (1986) Maturation and plasticity in the olfactory system of vertebrates. Brain Res. Rev. 99: 1-45.

Cauna, N., K. H. Hinderer, and R. T. Wentges (1969) Sensory receptor organs of the human nasal respiratory mucosa. Am. J. Anat. 124: 187-210.

Chiu, A. Y., W. D. Matthew, and P. W. Patterson (1986) A monoclonal antibody that blocks activity of a neurite regeneration promoting factor: Studies on the binding site and its location in vivo. J. Cell Biol. 103: 1383-1398. 
Chuah, M. I., and A. I. Farbman (1984) Olfactory bulb increases marker protein in olfactory receptor cells. J. Neurosci. 3: 2197-2205.

Chuah, M. I., A. I. Farbman, and B. Ph. M. Menco (1985) Influence of olfactory bulb on dendritic knob density of rat olfactory receptor neurons in vitro. Brain Res. 338: 259-266.

Chuong, C.-M., and G. M. Edelman (1984) Alterations in neural cell adhesion molecules during development of different regions of the nervous system. J. Neurosci. 4: 2354-2368.

Cuschieri, A. (1974) Enzyme histochemistry of the olfactory mucosa and vomeronasal organ in the mouse. J. Anat. 118: 477-489.

Cuschieri, A., and L. H. Bannister (1975a) The development of the olfactory mucosa in the mouse: Light microscopy. I. Anat. 119:277286.

Cuschieri, A., and L. H. Bannister (1975b) The development of the olfactory mucosa in the mouse: Electron microscopy. J. Anat. 119: 471-498.

Daniloff, J. K., C.-M. Chuong, G. Levi, and G. M. Edelman (1986) Differential distribution of cell adhesion molecules during histogenesis of the chick nervous system. J. Neurosci. 6: 739-758.

Edelman, G. M. (1984) Modulation of cell adhesion during induction, histogenesis, and perinatal development of the nervous system. Annu. Rev. Neurosci. 7: 339-377.

Edelman, G. M. (1985) Cell adhesion and the molecular processes of morphogenesis. Annu. Rev. Biochem. 54: 135-169.

Farbman, A. I. (1986) Prenatal development of mammalian olfactory receptor cells. Chem. Sens. 11:3-18.

Farbman, A. I., and F. L. Margolis (1980) Olfactory marker protein during ontogeny: Immunohistochemical localization. Dev. Biol. 74: 205-215.

Farbman, A. I., and B. Ph. M. Menco (1986) Development of olfactory epithelium in the rat. In Ontogeny of Olfaction. Principles of Olfactory Maturation in Vertebrates, W. Breipoh1, ed., pp. 45-56, SpringerVerlag, Berlin.

Farbman, A. I., and L. C. Squinto (1985) Early development of olfactory receptor cell axons. Dev. Brain Res. 19: 205-215.

Garrosa, M., S. Coca, and O. A. Mora (1986) Histological development of the vomeronasal complex in the pre- and postnatal rat. Acta Otolaryngol. 102: 291-301.

Gesteland, R. C., R. A. Yancey, and A. I. Farbman (1982) Development of olfactory receptor neuron selectivity in the rat fetus. Neuroscience 7: 3127-3136.

Gonzales, F., A. I. Farbman, and R. C. Gesteland (1985) Cell and explant culture of olfactory chemoreceptor cells. J. Neurosci. Methods 14: 77-90.

Graziadei, P. P. C., and G. A. Monti Graziadei (1978) Continuous nerve cell renewal in the olfactory system. In Handbook of Sensory Physiology, Vol. 9, M. Jacobson, ed., pp. 55-83, Springer-Verlag, Berlin.

Graziadei, P. P. C., and G. A. Monti Graziadei (1986) Principles of organization of the vertebrate olfactory glomerulus: An hypothesis. Neuroscience 19: 1025-1035.

Grumet, M., S. Hoffman, and G. M. Edelman (1984) Two antigenically related neuronal cell adhesion molecules of different specificities mediate neuron-neuron and neuron-glia adhesion. Proc. Natl. Acad. Sci. USA $81: 267-271$.

Hempstead, J. L., and J. I. Morgan (1983) Monoclonal antibodies to the rat olfactory sustentacular cell. Brain Res. 188: 289-295.

Hempstead, J. L., and J. I. Morgan (1985a) A panel of monoclonal antibodies to the rat olfactory epithelium. J. Neurosci. 5: 438-449.

Hcmpstcad, J. L., and J. I. Morgan (1985b) Monoclonal antibodies reveal novel aspects of the biochemistry and organization of olfactory neurons following unilateral olfactory bulbectomy. J. Neurosci. 5: 2382-2387.

Hinds, J. W. (1968a) Autoradiographic study of histogenesis in the mouse olfactory bulb. I. Time of origin of neurons and neuroglia. J. Comp. Neurol. 134: 287-304.

Hinds, J. W. (1968b) Autoradiographic study of histogenesis in the mouse olfactory bulb. II. Cell proliferation and migration. J. Comp. Neurol. 134: 305-322.

Hinds, J. W. (1972a) Early neuron differentiation in the mouse olfactory bulb. I. Light microscopy. J. Comp. Neurol. 146: 233-252.

Hinds, J. W. (1972b) Early neuron differentiation in the mouse olfactory bulb. II. Electron microscopy. J. Comp. Neurol. 146: 253276.

Hinds, J. W., and P. L. Hinds (1976) Synapse formation in the mouse olfactory bulb. I. Quantitative methods. J. Comp. Ncurol. 169: 1540.

Johnson, G. D., R. S. Davidson, K. C. McNamee, G. Russell, D. Goodwin, and E. J. Holborow (1982) Fading of immunofluorescence during microscopy: A study of the phenomenon and its remedy. J. Immunol. Methods 55: 231-242.

Keynes, R. J. (1987) Schwann cells during neural development and regeneration: Leaders or followers? Trends Neurosci. 10:137-139.

Kratzing, J. E. (1986) Morphological maturation of the olfactory epithelium of Australian marsupials. In Ontogeny of Olfaction. Principles of Olfactory Maturation in Vertebrates, W. Breipohl, ed., pp. 57-70, Springer-Verlag, Berlin.

Laemmli, U. K. (1970) Cleavage of structural proteins during the assembly of the head of bacteriophage T4. Nature 227:680-685.

Levitt, P., M. L. Cooper, and P. Rakic (1981) Coexistence of neuronal and glial precursor cells in the cerebral ventricular zone of the fetal monkey: An ultrastructural immunoperoxidase analysis: J. Neurosci. 1: $27-39$.

Lowry, O. H., N. J. Rosebrough, A. L. Farr, and R. J. Randall (1951) Protein measurement with the Folin phenol reagent. J. Biol. Chem. 193: 265-275.

Lyles, J. M., D. Linnemann, and E. Bock (1984) Biosynthesis of the D2-cell adhesion molecule: Post-translational modifications, intracellular transport, and developmental changes. J. Cell Biol. 99: 20822091.

Mair, R. G., R. C. Gesteland, and D. L. Blank (1982) Changes in morphology and physiology of olfactory receptor cilia during development. Neuroscience 7: 3091-3103.

Margolis, F. L., M. Grillo, T. Kawano, and A. I. Farbman (1985) Carnosine synthesis in olfactory tissue during ontogeny: Effect of exogenous $\beta$-alanine. J. Neurochem. 44: 1459-1464.

McLean, I. W., and P. K. Nakane (1974) Periodate-lysine-paraformaldehyde fixative. A new fixative for immunoelectron microscopy. J. Histochem. Cytochem. 22: 1077-1083.

Menco, B. Ph. M. (1988) Tight-junctional strands first appear in regions where three cells meet in differentiating olfactory epithelia. A freeze-fracture study. J. Cell Sci. 89: 495-505.

Menco, B. Ph. M., and A. I. Farbman (1985a) Genesis of cilia and microvilli of rat nasal epithelia during pre-natal development. I. OIfactory epithelium, qualitative studies. J. Cell Sci. 78: 283-310.

Menco, B. Ph. M., and A. I. Farbman (1985b) Genesis of cilia and microvilli of rat nasal epithelia during pre-natal development. II. Olfactory epithelium, a morphometric analysis. J. Cell Sci. 78: $311-$ 336.

Menco, B. Ph. M., and A. I. Farbman (1987) Genesis of cilia and microvilli of rat nasal epithelia during prenatal development. III. Respiratory epithelium surface, including a comparison with the surface of the olfactory epithelium. J. Anat. 152: 145-160.

Mendoza, A. S., and W. Breipohl (1983) The cell coat of olfactory epithelium proper and vomeronasal neuroepithelium of the rat as revealed by means of the Ruthenium-red reaction. Cell Tissue Res. 230: 139-146.

Mendoza, A. S., W. Breipohl, and F. Miragall (1982) Cell migration from the chick olfactory placodes: A light and electron microscopic study. J. Embryol. Exp. Morphol. 69: 47-59.

Meredith, M., D. Marques, R. J. O'Connell, and F. L. Stern (1980) Vomeronasal pump; significance for male hamster sexual bchavior. Science 207: 1224-1226.

Mollicone, R., J. Trojan, and R. Oriol (1985) Appearance of $\mathrm{H}$ and $B$ antigens in primary sensory cells of the rat olfactory apparatus and inner ear. Dev. Brain Res. 17: 275-279.

Monti Graziadei, G. A., and P. P. C. Graziadei (1979) Neurogenesis and neuron regeneration in the olfactory system of mammals. II. Degeneration and reconstitution of the olfactory sensory neurons after axotomy. J. Neurocytol. 8: 197-213.

Monti Graziadei, G. A., R. S. Stanley, and P. P. C. Graziadei (1980) The olfactory marker protein in the olfactory system of mouse during development. Neuroscience $5 \cdot 1239-1252$

Morgan, J. (1984) Monoclonal antibody production. In Modern Methods in Pharmacology, Vol. 2, S. Spector and N. Bach, eds., pp. 2967, Liss, New York.

Morgan, J. (1986) Immunological studies on the maturation of the rodent olfactory mucosa. In Ontogeny of Olfaction. Principles of $\mathrm{Ol}$ factory Maturation in Vertebrates, W. Breipohl, ed., pp. 95-103, Springer-Verlag, Berlin. 
Mori, K. (1987) Monoclonal antibodies (2C5 and 4C9) against lactoseries carbohydrates identify subsets of olfactory and vomeronasal receptor cells and their axons in the rabbit. Brain Res. 408: 215-221.

Morris, R. J., P. C. Barber, J. Reech, and G. Raisman (1983) The distribution of Thy-1 antigen in the P.N.S. of the adult rat. J. Neurocytol. 12: 1017-1039.

Moulton, D. G. (1974) Dynamics of cell populations in the olfactory epithelium. Ann. NY Acad. Sci. 237: 52-61.

Naguro, T., and W. Breipohl (1982) The vomeronasal epithelia of the NMRI mouse. A scanning electron-microscopic study. Cell Tissue Res. 227: 519-534.

O'Connell, R. J., and M. Meredith (1984) Effects of volatile and nonvolatile chemical signals on male sex behavior mediated by the main and accessory olfactory systems. Behav. Neurosci. 98: 1083-1093.

Pace, U., E. Hanski, Y. Salomon, and D. Lancet (1985) Odorantsensitive adenylate cyclase may mediate olfactory reception. Nature 316: 255-258.

Rehn, B., W. Breipohl, T. Naguro, and IJ. Schmidt (1982) Effect of $\mathrm{N}$-methyl-forimino-methylester on the vomeronasal neuroepithelium of mice. Cell Tissue Res. 225: 465-468.

Rutishauser, U. (1984) Developmental biology of neural cell adhesion molecules. Nature 310: 549-554.

Rutishauser, U. (1986) Differential cell adhesion through spatial and temporal variations of N-CAM. Trends Neurosci. 9: 374-378.

Rutishauser, U., W. E. Gall, and G. W. Edelman (1978) Adhesion among neural cells of the chick embryo. IV. Role of the cell surface molecule CAM in the formation of neurite bundles in cultures of spinal ganglia. J. Cell Biol. 79: 382-393.

Schwob, J. E., N. B. Farber, and D. I. Gottlieb (1986) Neurons of the olfactory epithelium in adult rats contain vimentin. J. Neurosci. 6 . 208-217.

Shat7., C. J., and M. B. Luskin (1986) The relationship between geniculocortical afferents and their cortical target cells during development of the cat's primary visual cortex. J. Neurosci. 6: 3655-3668.

Sklar, P. B., R. H. Anholt, and S. H. Snyder (1986) The odorantsensitive adenylate cyclase of olfactory receptor cells. J. Biol. Chem. 261: $15538-15543$
Smart, I. M. H. (1971) Location and orientation of mitotic figures in the developing mouse olfactory epithelium. J. Anat. 109: 243-251.

Taniguchi, K., K. Taniguchi, and K. Mochizuki (1982a) Developmental studies on the vomeronasal organ in the golden hamster. Jpn. J. Vet. Sci. 44: 709-716.

Taniguchi, K., K. Taniguchi, and K. Mochizuki (1982b) Comparative developmental studies on the fine structure of the vomeronasal sensory and the olfactory epithelia in the golden hamster. Jpn. J. Vet. Sci. 44: 881-890.

Taniguchi, K., K. Taniguchi, and S. Mikami (1986) Devclopmental studies on enzyme histochemistry of the three olfactory epithelia in the golden hamster. In Ontogeny of Olfaction. Principles of Olfactory Maturation in Vertebrates, W. Breipohl, ed., pp. 83-94, SpringerVerlag, Berlin.

Telser, A., A. I. Farbman, and C. Chacko (1982) A low-molecularweight soluble protein from bovine lingual epithelium. II. Purification and characterization. J. Invest. Dermatol. 79: 286-292.

Tosney, K. W., and L. T. Landmesser (1985) Development of the major pathways for neurite outgrowth in the chick hindlimb. Dev. Biol. 109: 193-214.

Towbin, H., T. Staehlin, and J. Gordon (1979) Electrophoretic transfer of proteins from polyacrylamide gels to nitrocellulose sheets: Procedure and some applications. Proc. Natl. Acad. Sci. USA 76: 43504354.

Tucker, D. (1971) Nonolfactory responses from the nasal cavity: Jacobson's organ and the trigeminal system. In Handbook of Sensory Physiology, Vol. 4, L. M. Beidler, ed., pp. 151-180, Springer-Verlag, Berlin.

Williams, R. K., C. Goridis, and R. Akeson (1985) Individual neuronal cell types express immunologically distinct N-CAM forms. J. Cell Biol. 101: 36-42.

Winans, S. S., and J. B. Powers (1977) Olfactory and vomeronasal deafferentation of male hamsters: Histological and behavioral analyses. Brain Res. 126: 325-344.

Wysocki, C. J., J. L. Wellington, and G. K. Beauchamp (1980) Access of urinary nonvolatiles to the mammalian vomeronasal organ. Science 207: 781-783. 